
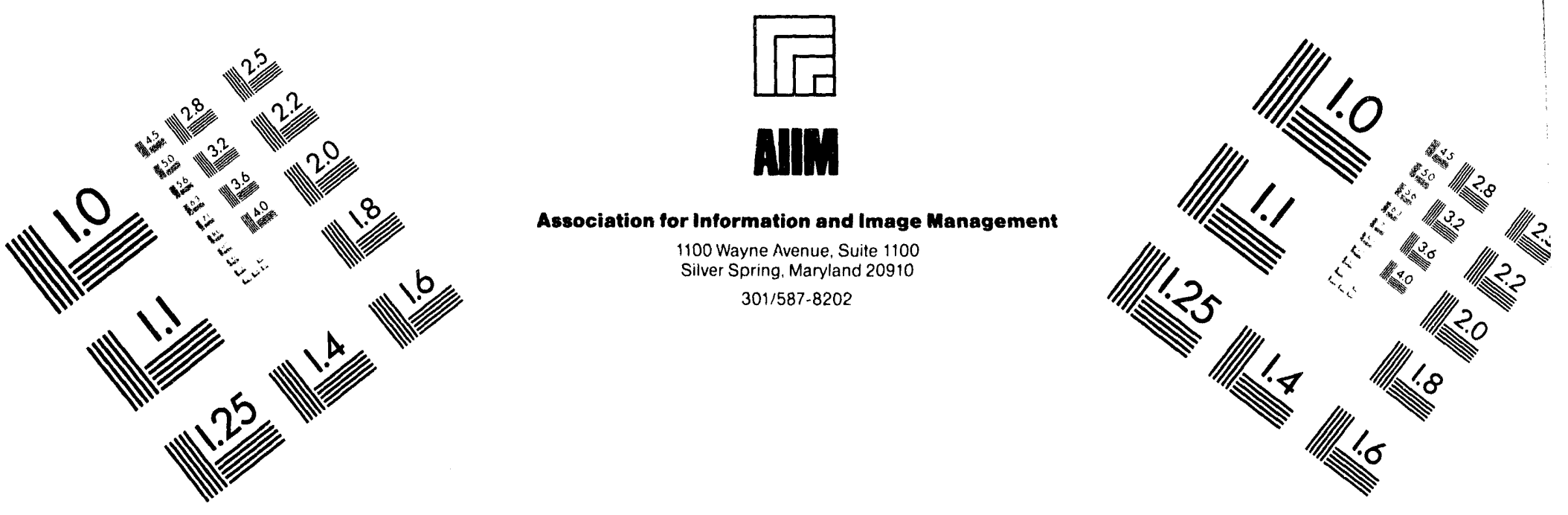

\title{
Centimeter
}

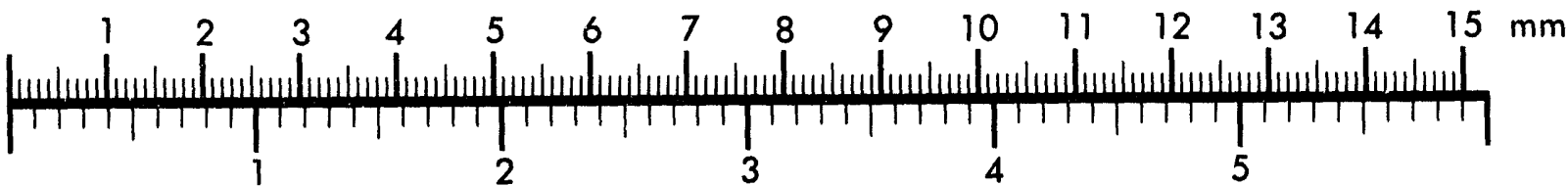
Inches
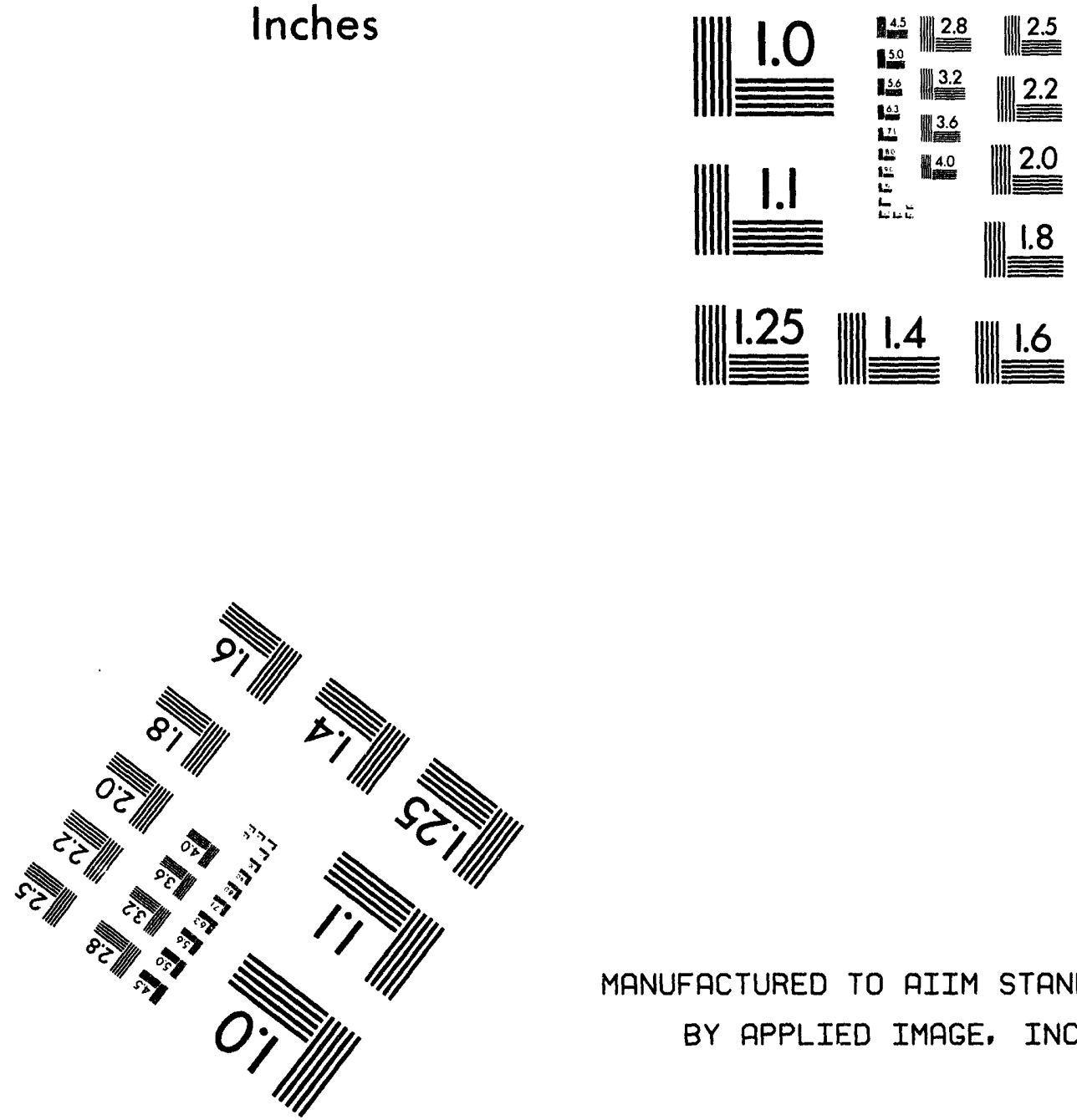

MANUFACTURED TO AIIM STANDARDS BY APPLIED IMAGE, INC.

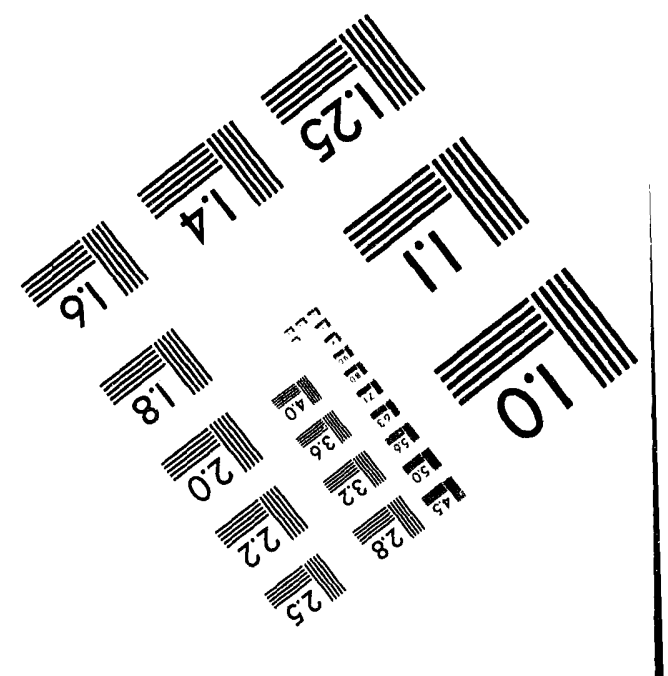



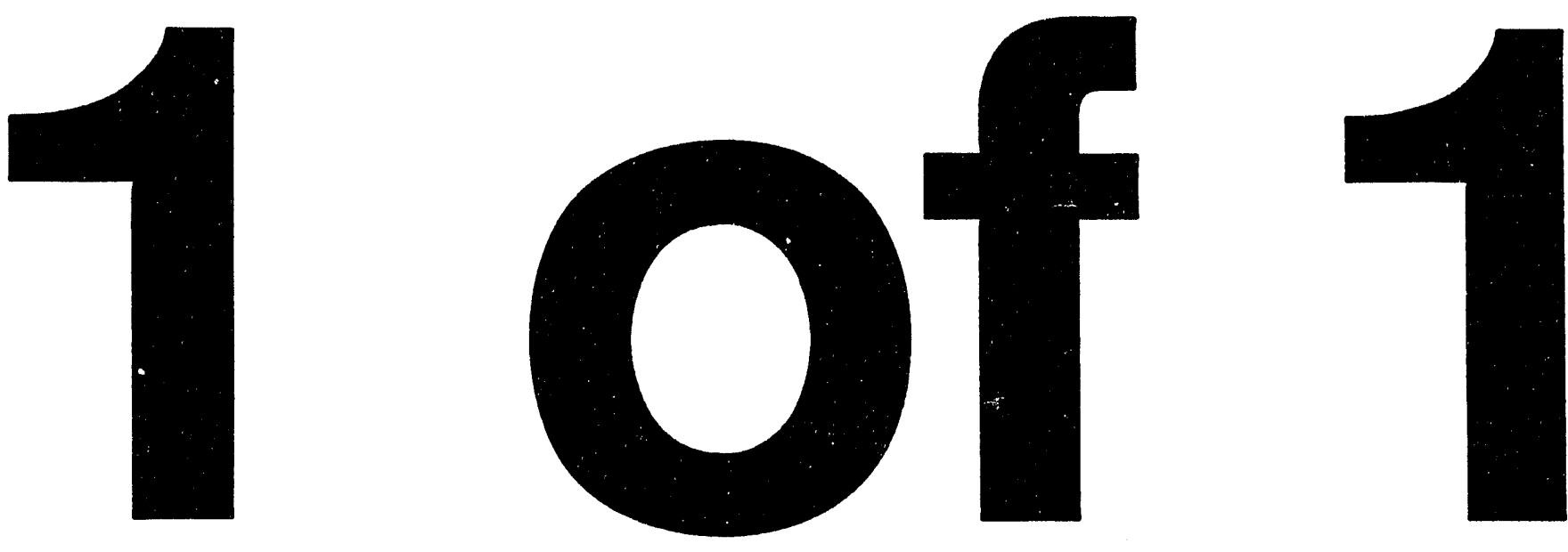


\section{National Emission Standards for Hazardous Air Pollutants Submittal - 1993}

Stuart C. Black

June 1994

Work Performed Under Contract No.

DE-ACO8-94NV11432

Prepared by:

Reynolds Electrical \& Englineering Co., Inc.

Post Office Box 98521

Las Vegas, Nevada 89193-8521 


\section{TABLE OF CONTENTS}

Page

List of Figures $\ldots \ldots \ldots \ldots \ldots \ldots \ldots \ldots \ldots \ldots \ldots \ldots \ldots \ldots \ldots \ldots \ldots \ldots$ iv

List of Tables $\ldots \ldots \ldots \ldots \ldots \ldots \ldots \ldots \ldots \ldots \ldots \ldots \ldots \ldots \ldots \ldots \ldots \ldots$, iv

List of Acronyms $\ldots \ldots \ldots \ldots \ldots \ldots \ldots \ldots \ldots \ldots \ldots \ldots \ldots \ldots \ldots, v$

Operations Office and Site Information $\ldots \ldots \ldots \ldots \ldots \ldots \ldots \ldots \ldots \ldots \ldots, 1$

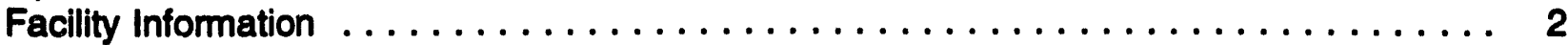

Site Description .................................... 2

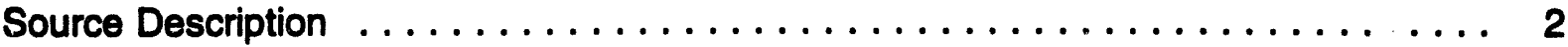

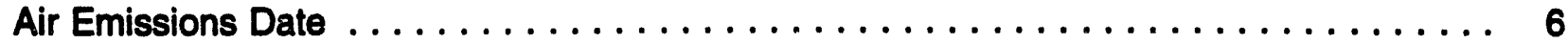

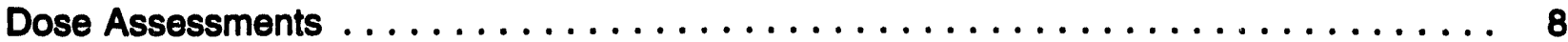

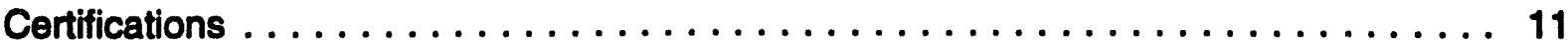

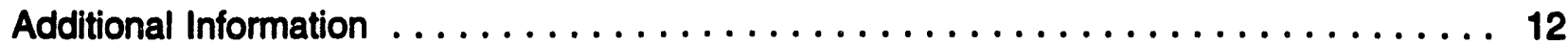

APPENDICES

Lawrence Livermore National Laboratory $\ldots \ldots \ldots \ldots \ldots \ldots \ldots \ldots \ldots \ldots$ A-1

Los Alamos National Laboratory . . . . . . . . . . . . . . . . . . B-1

Defense Nuclear Agency . ............................ C-1

Laboratory Radionuclide Inventory $\ldots \ldots \ldots \ldots \ldots \ldots \ldots \ldots \ldots \ldots \ldots \ldots \ldots \ldots \ldots \ldots$

Emissions from Tunnels and Ponds $\ldots \ldots \ldots \ldots \ldots \ldots \ldots \ldots \ldots \ldots \ldots \ldots \ldots \ldots$

Resuspended Plutonium from Yucca Flat $\ldots \ldots \ldots \ldots \ldots \ldots \ldots \ldots \ldots$ F-1

Diffuse Source Atmospheric Tritium Emissions $\ldots \ldots \ldots \ldots \ldots \ldots \ldots \ldots \ldots$ G-1

Noble Gas Seepage on Pahute Mesa ........................ H-1

Meteorological Data for Input to CAPB8-PC $\ldots \ldots \ldots \ldots \ldots \ldots \ldots \ldots \ldots$ I-1

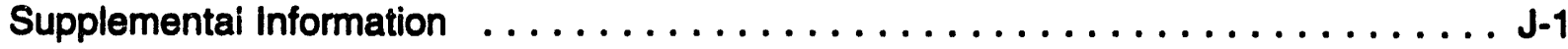




\section{LIST OF FIGURES}

Page

Figure 1 Map of the Area Around the NTS .................. 13

Figure $2 \quad$ Nuclear Testing Areas on the Nevada Test Site ... . . . . . . . . . . 14

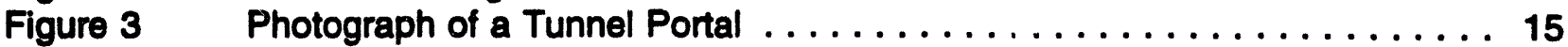

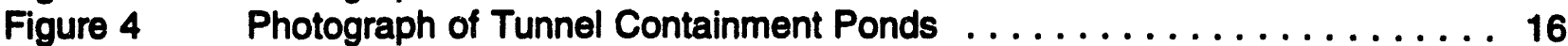

Figure $5 \quad$ Building 650 Hood Ventilation Stacks Seen from Above . . . . . . . . . . . 17

Figure $6 \quad$ Locations of Nuclear Device Safety Tests on the NTS . . . . . . . . . . . . 18

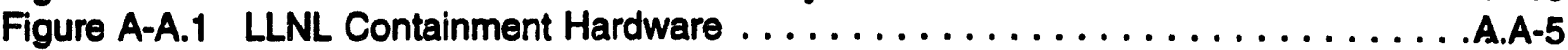

Figure B.1 LANL Containment Hardware . . . . . . . . . . . . . . . . . . B-5

Figure C.1 FCNV Organization and Operational Responsibilities . . . . . . . . . . . C-2

Figure C.2 Typical Tunnel Layout for Nuclear Tests . . . . . . . . . . . . . . . . C-4

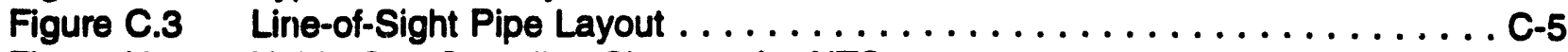

Figure H.1 Noble Gas Sampling Sites on the NTS . . . . . . . . . . . . . . H-3

Figure H.2 Wind Roses for the Various Areas on the NTS . . . . . . . . . . . . H-4

Figure $1.1 \quad$ Location of MEDA Stations on the NTS $\ldots \ldots \ldots \ldots \ldots \ldots \ldots$

\section{LIST OF TABLES}

Table 1 Summary of Estimated Inventory of ${ }^{230+240} \mathrm{Pu}$ in Surface Soil . . . . . . . . . 5

Table 2 Summary of Air Emissions Data by Source . . . . . . . . . . . . . 7

Table $3 \quad$ Total Emissions for CY $1993 \ldots \ldots \ldots \ldots \ldots \ldots \ldots \ldots \ldots \ldots \ldots$

Table 4 Summary of CY 1993 CAP88-PC Calculations of EDE . . . . . . . . . . 9

Table 5 Effective Dose Equivalent Tabulation by Location . . . . . . . . . . . . 10

Table A.1 List of Radioactive Effluents and Probability of Occurrence . . . . . . . . . A-2

Table A-2 Effective Dose Equivalents . . . . . . . . . . . . . . . . . . A-3

Table A.A-1 Effluents and Monitoring ........................A.1

Table C.1 Operational Responsibilities by FCNV Division $\ldots \ldots \ldots \ldots \ldots \ldots \ldots \ldots$. . . . . .

Table D.1 Bldg. 650 Health Physics Laboratory Radionuclide Inventory . . . . . . . . . D-1

Table E.1 Tritium Effluents into Containment Ponds . . . . . . . . . . . . . . . . . E-1

Table F.1 Airborne ${ }^{239+210}$ Pu Detected by Area 3 Air Samplers . . . . . . . . . . . . . . . . F-1

Table G.1 Airborne Tritium Sampling Results During CY $1993 \ldots \ldots \ldots \ldots \ldots$. . . . . . . . G-2

Table H.1 85Kr Concentrations on the NTS in $1993 \ldots \ldots \ldots \ldots \ldots \ldots \ldots \ldots . \ldots . . \ldots . . . \ldots$ 


\section{LIST OF ACRONYMS}

$\begin{array}{ll}\text { DNA } & \text { Defense Nuclear Agency } \\ \text { EDE } & \text { Effective Dose Equivalent } \\ \text { EIS } & \text { Effluent Information System } \\ \text { ES\&H } & \text { Environment, Safety and Health } \\ \text { FCNV } & \text { Field Command, Nevada } \\ \text { GCD } & \text { Greater confinement disposal } \\ \text { HEPA } & \text { High efficiency particulate air - an air filter } \\ \text { HTO } & \text { Tritiated water } \\ \text { LANL } & \text { Los Alamos National Laboratory } \\ \text { LGFSTF } & \text { Liquified Gaseous Fuels Spill Test Facility } \\ \text { LLNL } & \text { Lawrence Livermore National Laboratory } \\ \text { LOS } & \text { Line-of-sight } \\ \text { MDC } & \text { Minimum detectable concentration } \\ \text { MEDA } & \text { Meteorological Data Acquisition System } \\ \text { MEI } & \text { Maximally exposed individual } \\ \text { NESHAP } & \text { National Emission Standard for Hazardous Air Pollutants } \\ \text { NOAA } & \text { National Oceanic and Atmospheric Administration } \\ \text { NTOD } & \text { Nuclear Test Operations Division } \\ \text { NTS } & \text { Nevada Test Site } \\ \text { Pu } & \text { Plutonium } \\ \text { REECo } & \text { Reynolds Electrical \& Engineering Co., Inc. } \\ \text { RWMS } & \text { Radioactive Waste Management Site } \\ \text { STAR } & \text { Stability Array - grouping of meteorological data } \\ \text { TRU } & \text { Transuranic - nuclides with atomic numbers greater than uranium } \\ \text { WSNSO } & \text { Weather Service Nuclear Support Office (1n 1994 became ARLSORD) }\end{array}$




\section{U.S. Department of Energy}

Air Emissions Annual Report

(under Subpart H, 40 CFR 61.94)

Calendar Year 1993

Site Name: NEVADA TEST SITE

Operations Office Information

Office: DOE Nevada Operations Office

Address: $\quad$ P. 0. Box 98518

Las Vegas, NV 89193-8518

Contact: Donald R. Elle, Ph, D. Director

Phone:(702) 295-1146

Environmental Protection Division

Site Information

Operator: Reynolds Electrical \& Engineering Co.. Inc.

Address: $\quad$ P. O. Box 98521

Las Vegas, NV 89193-8521

Contact: Howard W. Dickson, Manager

Phone:1702) 295-3379

Environmental Management Division 


\section{SECTION I \\ FACILITY INFORMATION}

\section{SITE DESCRIPTION}

The Nevada Test Site (NTS) is operated by the Nevada Operations Office, U.S. Department of Energy, as the site for nuclear weapons testing. It is located in Nye County, Nevada, with the southeast comer about $90 \mathrm{~km}$ (56 mi) northwest of Las Vegas, NV. The NTS covers about $3500 \mathrm{~km}^{2}$ (1350 $\mathrm{mi}^{2}$ ), an area larger than Rhode Island. Its size being about 46 to $56 \mathrm{~km}$ (28 to $35 \mathrm{mi}$ ) east to west and from 64 to $88 \mathrm{~km}$ ( 40 to $55 \mathrm{mi}$ ) north to south. The NTS is surrounded, except on the south side, by public exclusion areas (Nellis Base Range) that provide another 24 to $104 \mathrm{~km}$ (15 to 65) miles between the NTS and public lands (Figure 1). The NTS is characterized by desert valley and Great Basin mountain topography, with a climate, flora, and fauna typical of the southwest deserts. Population density within $150 \mathrm{~km}$ (93 mi.) of the NTS is only about 0.5 persons per square kilometer, excluding the Las Vegas area. Restricted access, low population density in the surrounding area and extended wind transport times are advantageous factors for the activities conducted at the NTS. Surface waters are scarce on the NTS and the depth to slow-moving groundwater is great.

\section{SOURCE DESCRIPTION}

Figure 2 is a map of the NTS which shows the areas used for nuclear testing. The NTS has been the primary location for testing of nuclear explosives in the Continental U.S. since 1951. Historical testing has included (1) atmospheric testing in the 1950s and early 1960s, (2) earthcratering experiments, and (3) open-air nuclear reactor and rocket engine testing. Since the mid 1960s, testing of nuclear devices has occurred underground in drilled vertical holes or in mined tunnels. No such tests were conducted in 1993. Limited non-nuclear testing has included spills of hazardous material at the Liquified Gaseous Fuels Spill Test Facility (LGFSTF). Processing of radioactive materials is limited to laboratory analyses. Handling of these materials is limited to transport, assembly, and underground placement of nuclear explosive devices and operation of a radioactive waste management site (RWMS) for lowlevel radioactive and mixed waste. Monitoring and evaluation of the various activities conducted onsite indicate that the potential sources of offsite radiation exposure in 1993 were releases: (1) from evaporation of tritiated water from containment ponds that receive drainage water from tunnels E, N, and T in Area 12; (2) from onsite radioanalytical laboratories; (3) from the Area 5 RWMS facility; (4) from other diffuse sources; and (5) from P Tunnel air effluents The following sections present a general description of the effluent sources on the NTS.

\section{Ground Seepage of Noble Gases}

Ground seepage may occur when changes in ambient pressure pump small amounts of noble gases up through the overburden and into the atmosphere from the cavity created by a nuclear test. This process, sometimes referred to as "atmospheric pumping", creates a diffuse source of radiological effluents. These area sources are rare and therefore not routinely monitored. The phenomenon is usually restricted to events conducted in the Pahute Mesa region of NTS. These seepages are from nuclear tests conducted prior to 1993.

Krypton-85 was detected at all environmental sampling locations on the NTS as it has been in previous years. The Area 20 environmental sampler was about $2 \mathrm{pCi} / \mathrm{m}^{3}\left(0.07 \mathrm{~Bq} / \mathrm{m}^{3}\right)$ above the onsite network average, but the precise source is unknown. Assuming this 
seepage occurs from an area under which several underground tests were conducted, a source term can be calculated as shown in Appendix $H$.

\section{Tunnel Operations}

Nuclear tests are sometimes conducted within tunnel complexes mined into the Rainier Mesa region. Although no nuclear explosives tests were conducted in 1993, analysis of the airbome radiological contaminants was performed on samples collected at the discharge point of the tunnel air. Figure 3 is a photograph of a tunnel portal and Appendix $C$ contains the Defense Nuclear Agency (DNA) procedures for this activity. Isokinetic sampling equipment has been installed in P Tunnel and was operated by REECo to obtain confirmatory measurements of tunnel air emissions.

\section{Containment Ponds}

Radiologically contaminated water seeps from the tunnels in Area 12. This water is held within containment ponds where some evaporates and some seeps into the soil. A photograph of tunnel containment ponds is provided as Figure 4. The only significant radiological contaminant which produces an air emission from evaporation of the water is ${ }^{3} \mathrm{H}$ (as HTO). The tunnel complexes are being sealed and the discharge is decreasing. It is expected to cease completely in a year or so. The calculation of the source term is described in Appendix E.

\section{Drillbacks}

Following underground nuclear tests, core samples are taken from the cavity formed by the nuclear detonation, for analysis and diagnosis. This is referred to as core-sampling and is accomplished by drilling into the area of interest and recovering samples using special drilling equipment. Radioactive material may be discharged into the atmosphere during these operations. Because of different engineering designs, there are two methods for handling potential effluents during drillbacks. These are described in Appendices A and B. There were no drillbacks in 1993.

\section{Laboratoriss}

Radiological analyses are conducted by REECo in a laboratory located in Building 650, and Los Alamos National Laboratory (LANL) conducts similar analyses in Building 701 at Mercury (see Appendix B). Because these facilities primarily process environmental samples, very little radicactivity passes through them. However, there is potential for some radionuclides to be discharged into the atmosphere through the hood ventilation system during sample processing, particularly of spiked samples, or from loss of radioactive standards. Figure 5 is a photograph of the Building 650 hood ventilation stacks seen from above. The source term for Building 701 is contained in Appendix B and for Building 650 in Appendix D. In general, evaporation and spills from samples containing HTO, radioiodines, or noble gases is conservatively estimated by assuming all such materials are released. Non-volatile materials are controlled by keeping their inventory below the possession limits set forth in Appendix E to 40CFR61. 


\section{Area 5 Radioactive Waste Management Site (RWMS)}

This site is used for the disposal of low-level waste, for storage of transuranic (TRU) and mixed TRU wastes, and contains the Greater Confinement Disposal (GCD) Test Unit and 12 GCD boreholes (only a few have any waste). Disposal is accomplished by the use of pits and trenches; concrete pads are used for temporary storage of certain wastes. Only packaged wastes are accepted for disposal. The facility is considered a diffuse source of radiological effluents. The only radioactive effluent picked up by the various types of samplers surrounding the site is HTO in atmospheric moisture. The calculation of the HTO source term is explained in Appendix $G$.

\section{Plutonium Contaminated Surface Areas}

Surface soils in certain areas on and off of the NTS were contaminated with plutonium from either safety, atmospheric, or cratering (the Plowshare Program) tests using nuclear explosives. An investigation of these areas during the Nevada Applied Ecology Group studies developed the inventories of plutonium shown in Table 1. These areas could become sources of plutonium exposure if the contaminated soils were to be resuspended, e.g., during surface cleanup, construction, or similar activities. Figure 6 is a map showing the approximate locations of the nuclear device safety tests on the NTS. There are air samplers at or near almost all of these onsite areas. Plutonium analyses of the glass-fiber filters from these samplers indicates that the majority of the results are less than the minimum detectable concentration (MDC) and most of those are even less than the 2 standard deviation (2s) counting error. The results that are different are from air samplers in Yucca Flat where operational activities can cause contaminated surface soil to become resuspended. This area is considered a diffuse source of radioactive effluents, although plutonium is the only detectable one. The calculation of the source term is explained in Appendix F. 
Table 1. Summary of Estimated Inventory of ${ }^{230+240} \mathrm{Pu}$ in Surface $\varepsilon_{\text {sii: }}(0$ to $5 \mathrm{~cm})$ at Studied Sites

\begin{tabular}{|c|c|c|c|c|c|}
\hline SITE (ON NTS) & AREA $\left(\mathrm{km}^{2}\right)$ & $\begin{array}{l}\text { NUMBER } \\
\text { SAMPLES }\end{array}$ & $\begin{array}{l}\text { EST. INVENTORY } \\
\text { (CURIES) }\end{array}$ & $\begin{array}{l}95 \% \\
\text { CONF.INTERVAL } \\
\text { (CURIES) }\end{array}$ & $\begin{array}{l}{ }^{230+200} \text { Pu AIR CONC. } \\
\text { ANNUAL AVG. }(X \pm 2 s) \\
\text { IN } 10^{-18} \mu C V / m L \text { units }\end{array}$ \\
\hline PROJECT 56 (AREA 11)(1) & 4.83 & 205 & 36 & $28-44$ & $23 \pm 39$ \\
\hline GMX (AREA 5) ${ }^{(1)}$ & 0.125 & 111 & 1.5 & $1.1-1.9$ & $5 \pm 5$ \\
\hline LITTLE FELLER 川(Area 18)(1) & 0.375 & 712 & $32^{(3)}$ & $22-41$ & \\
\hline PALANQUIN* (AREA 20) ${ }^{(2)}$ & 3.895 & 148 & $13^{(3)}$ & $6-21$ & $1.6 \pm 1.2$ \\
\hline SEDAN (AREA 10) ${ }^{(2)}$ & 28.264 & & 111.2 & & $12 \pm 13$ \\
\hline T2 SERIES (AREA 2) ${ }^{(4)}$ & 30.100 & & 26.7 & & $8 \pm 16$ \\
\hline VARIOUS TESTS (AREA 9) & & & 89 & & $245 \pm 216$ \\
\hline
\end{tabular}

(1) Safety tests of nuclear devices.

(2) Plowshare tests (Palanquin and Cabriolet sites in Area 20 combined)

(3) Inventory consists of ${ }^{200+240} \mathrm{Pu}+{ }^{241} \mathrm{Am}$.

(Gilbert, NVO-181 p. 425; NVO-272, pp. 381-429; McArthur, DOENV10162-20)

(4) Weapons effects tests. 


\section{SECTION II \\ AIR EMISSIONS DATA}

Each potential source of NTS emissions was characterized by one of the following: (1) by monitoring methods and procedures previously developed at NTS (see Appendices A, B, and C), (2) by a yearly radionuclide inventory of the source, assuming that volatile radionuclides are released to the environment, (3) by the measurement of tritiated water (as $\mathrm{HTO}$ or $\mathrm{T}_{2} \mathrm{O}$ ) concentration in liquid effluents discharged to containment ponds and assuming all the effluent evaporates over the course of the year to become an air emission, or (4) by using a combination of environmental measurements and CAP88-PC to calculate emissions. Appendices $A$ through $\mathrm{J}$ describe the methods used to determine the ernissions from the sources listed in Section I. In accordance with 40 CFR 61.93.(b).(4), no credit was taken for pollution control equipment in determining air emissions.

These National Emission Standards for Hazardous Air Pollutants (NESHAP) emissions are listed in Table 2, are very conservative (worst case), are used in Section III to calculate the effective dose equivalent (EDE) to the Maximally Exposed Individual offsite (MEI), and exceed, in some cases, those reported in DOE's Effluent Information System (EIS). The NESHAPs worst case emissions that exceed the EIS reported emissions are noted by a (1) in Table 2.

A summary of the NTS total emissions for NESHAPs reporting, by radionuclide, is provided in Table 3.

Table 3. Total Emissions for CY 1993 (Multiply Ci by 37 to obtain GBq)

\begin{tabular}{|c|c|c|}
\hline Radionuclide & Half-Life (days) & Annual Quantity (Ci) \\
\hline${ }^{3} \mathrm{H}$ & 4510 & 708 \\
\hline${ }^{85} \mathrm{Kr}$ & $3.9 \times 10^{3}$ & 160 \\
\hline${ }^{130} \mathrm{Xe}$ & 5.24 & $4.0 \times 10^{-2}$ \\
\hline 131 & 8.04 & $2.0 \times 10^{-6}$ \\
\hline${ }^{239+240} \mathrm{Pu}$ & $8.8 \times 10^{6}$ & $1.8 \times 10^{-3}$ \\
\hline
\end{tabular}

Note: This table includes all worst case point and diffuse source releases. Actual estimated releases are reported on DOENV Effluent Information System reports. 
Table 2. Summary of Annual Air Emissions Data by Source (Multiply Ci by $\mathbf{3 7}$ to obtain GBq)

\begin{tabular}{|c|c|c|c|c|c|}
\hline$\frac{\text { Point }}{\text { Source }}$ & $\frac{\text { Trpe of }}{\text { Control }}$ & Efficiency & $\begin{array}{l}\text { Distance te } \\
\text { Nearest Receptor }\end{array}$ & Nuclide & Quantity (Ci) \\
\hline Building 701 'II & None & $0 \%$ & $24 \mathrm{~km}$ & $\begin{array}{l}{ }^{3} \mathrm{H} \\
{ }^{131} 1_{1} \\
{ }^{133} \mathrm{Xe}_{\theta}\end{array}$ & $\begin{array}{l}5.0 \times 10^{-4} \\
2.0 \times 10^{-6} \\
4.0 \times 10^{-2}\end{array}$ \\
\hline P-Tunnel & None & $0 \%$ & 56 km & ${ }^{3} \mathrm{H}$ & 3.7 \\
\hline \multicolumn{6}{|l|}{$\begin{array}{l}\text { Grouped } \\
\text { Sources }\end{array}$} \\
\hline $\begin{array}{l}\text { Building } 650 \text { (1) } \\
\text { Laboratory (12) }\end{array}$ & None & $0 \%$ & 24 km & ${ }^{3} \mathrm{H}$ & $1.3 \times 10^{-5}$ \\
\hline $\begin{array}{l}\text { Containment } \\
\text { Pond: Area } 12\end{array}$ & None & $0 \%$ & 56 km & ${ }^{3} \mathrm{H}$ & 704 \\
\hline \multicolumn{6}{|l|}{$\begin{array}{l}\text { Non-Point } \\
\text { Sources }\end{array}$} \\
\hline $\begin{array}{l}\text { Yucca Flat: }{ }^{131} \\
\text { Area } 3 \\
\text { Area } 9 \\
\text { RWMS }\end{array}$ & $\begin{array}{l}\text { None } \\
\text { None } \\
\text { None }\end{array}$ & $\begin{array}{l}0 \% \\
0 \% \\
0 \%\end{array}$ & $\begin{array}{l}54 \mathrm{~km} \\
53 \mathrm{~km} \\
42 \mathrm{~km}\end{array}$ & $\begin{array}{l}239+240 \mathrm{Pu} \\
239+240 \mathrm{Pu} \\
{ }^{3} \mathrm{H}\end{array}$ & $\begin{array}{l}1.0 \times 10^{-3} \\
0.8 \times 10^{-3} \\
0.29\end{array}$ \\
\hline $\begin{array}{l}\text { Pahute Mesa }{ }^{(3)} \\
\text { (Ground Seepage) }\end{array}$ & None & $0 \%$ & $42 \mathrm{~km}$ & ${ }^{85} \mathrm{Kr}$ & 160 \\
\hline $\begin{array}{l}\text { (x) is number of ve } \\
\text { (1) Not on the EIS Re } \\
\text { (2) Evaporation of all } \\
\text { (3) Emissions based } 0\end{array}$ & $\begin{array}{l}\text { s. } \\
\text { al iwors } \\
\text { er efflue } \\
\text { ntal sur }\end{array}$ & ions only. & & & \\
\hline
\end{tabular}




\section{SECTION III \\ DOSE ASSESSMENTS}

\section{SUMMARY OF INPUT PARAMETERS}

CAP88-PC was used to calculate effective dose equivalents to offsite residents. The input parameters were the radionuclide releases listed in Section II above as determined from effluent monitoring performed by the NTS operating contractor (REECo) and from calculations of diffuse source emissions that are based on environmental monitoring data. The latter include measurable particulate emissions of ${ }^{230+240} \mathrm{Pu}$ originating in certain areas of Yucca Flat, diffusion of ${ }^{85} \mathrm{Kr}$ from Pahute Mesa, and HTO detected on the RWMS perimeter.

To calculate the amount of tritiated water (HTO) evaporated, measurements of HTO concentration in the containment ponds were compared for February 1992 and December 1992. These concentrations were equal, i.e., within the measurement error, and the surface areas were approximately equal, so all the HTO influent to the ponds during 1992 was assumed to have evaporated, a conservative estimate as no allowance for infiltration into the soil column is made. This procedure was followed in 1993, also. A description of the estimated source term for these emission sources is contained in the Appendices.

The source data listed above are used with five stability array (STAR) data files as input to CAP88-PC. The five STARs for the NTS include the files with names NTSYUCCA, AREA05, MEDA20, DESERTRK, and T-Tunnel. NTSYUCCA is used for sources on Yucca Flat (Areas $1,2,3,4,6,7$, and 9), AREA05 is used for sources on Frenchman Flat, DESERTPK is used for sources in Mercury, MEDA20 is used for sources in Areas 19 and 20, and T-Tunnel for the tunnel pond sources in Area 12. MEDA20, T-Tunnel and AREA05 were daveloped by the Weather Service Nuclear Support Office (WSNSO) using data obtained from the meteorological stations located near the boundary of Areas 19 and 20 on Pahute Mesa, near the tunnels in Area 12, and at Well 5B in Area 5. The other two files were provided by the National Climatic Data Center in North Carolina based on data from meteorological stations in Yucca. Flat and at Desert Rock airstrip. The WSNSO assessment is attached as Appendix I. For each of these five STARs there may be a different location for the maximally exposed individual, but, when the contributions of all NTS sources are considered, only one location would receive the maximum exposure, Indian Springs, Nevada.See Figure 1 for location of residences and communities around the NTS.

The EDE, in mrem, to the maximally exposed individual (a resident in Indian Springs, NV) was calculated using CAP88-PC for each of the listed sources in Section II. A summary of sources contributing to the EDE is shown in Table 4. Calculation of this EDE requires summing the contribution from all sources as shown in Table 5. The sources listed as containment ponds in Area 12, and Laboratory Buildings 650 and 701 (Mercury) were added to the NESHAP program in 1991 for 1990 emissions. Consideration of diffuse sources, such as soils contaminated by safety and other nuclear device tests were added in the 1992 report to complete the possible sources of emission of radioactivity on the NTS. Appendices A through $\mathrm{J}$ contain estimates of radionuclides which could be released from each source.

Descriptions and estimations of the errors involved in each step of the process (measurement, monitoring, and calculation), estimations of potential releases, and worst case scenarios are also included. 
Table 4. Summary of CY 1993 CAP88-PC Calculations of EDE to the Maximally Exposed Offsite Individual - Indian Springs, Nevada (a)

\begin{tabular}{|c|c|c|}
\hline Source & $\begin{array}{l}\text { ance to Individual } \\
\text { and Direction }\end{array}$ & $\frac{\text { Effective Dose Equivalent }}{\text { (mrem) }}$ \\
\hline Tunnel monitoring (Area 12) & $80 \mathrm{~km}$ SSE & $3.4 \times 10^{-3010}$ \\
\hline Laboratories (Area 23) & 34 km ESE & $5.7 \times 10^{-6}$ \\
\hline $\begin{array}{l}\text { Yucca Flat (Area 3) } \\
\text { (Area 9) }\end{array}$ & $\begin{array}{l}64 \mathrm{~km} \mathrm{SE} \\
67 \mathrm{~km} \text { SSE }\end{array}$ & $\begin{array}{l}1.2 \times 10^{4} \\
2.4 \times 10^{-4}\end{array}$ \\
\hline RWMS (Area 5) & $42 \mathrm{~km}$ SE & $4.1 \times 10^{-6}$ \\
\hline Pahute Mesa (Ares 19-20) & $100 \mathrm{~km} \mathrm{SE}$ & 0 \\
\hline
\end{tabular}

(a) Location of residences and communities around the NTS is shown in Figure 1

(b) For mSv, multiply by $10^{-2}$

(c) Assumes eveporation of all tritiated water influents to ponds

NOTE: To two significant figures, the MEI dose was due to diffuse emission sources. Therefore, the EDE from point sources was negligible. 
Table 5. Effective Dese Equivalent Tabulation by Location (Multiply mrem by $10^{-2}$ for equivalent $\mathrm{mSv}$ units)

\begin{tabular}{|c|c|c|c|c|c|c|c|c|}
\hline \multirow[t]{2}{*}{ LOCATION } & \multirow[t]{2}{*}{ POP.9 } & \multicolumn{6}{|c|}{ EDE ( $\left.10^{\circ} \mathrm{mrem} / \mathrm{TEAR}\right)$ DUE TO RELEASES FROM: } & \multirow{2}{*}{$\begin{array}{l}\text { COLLCTME } \\
\text { EDE } \\
\text { MAN-MREM }\end{array}$} \\
\hline & & $\begin{array}{l}\text { AREA 12(1) } \\
\text { TRITIUM }\end{array}$ & $\begin{array}{l}\text { PAHUTE } \\
\text { MESA'" } \\
\end{array}$ & $\begin{array}{l}\text { YUCCCA FLAT } \\
\text { AREA } 3^{(1)} \text { AREA } 9^{(1)}\end{array}$ & $\begin{array}{l}\text { AREA 5(1) } \\
\text { RWMS }\end{array}$ & ${ }_{\mathrm{LABS}}^{\mathrm{AREA}}$ & $\begin{array}{l}\text { TOTAL EDE } \\
\text { 10 }\end{array}$ & \\
\hline AMARGOSA VALLEY & 950 & 1600 & 0.6 & 310 & 3.9 & 0.014 & 2.2 & 2.1 \\
\hline ASH MEADOWS & 10 & $\left(\right.$ see note $\left.{ }^{4}\right)$ & & 330 & 2.7 & 0.011 & 0.33 & $3.3 \times 10^{3}$ \\
\hline BEATTY & 1500 & 1500 & 1.3 & 400 & 4.0 & 0.011 & 2.2 & 3.3 \\
\hline CRYSTAL & 45 & 2600 & & 300 & 4.1 & 0.02 & 3.1 & $1.4 \times 10^{-1}$ \\
\hline DEATH VALLEY JCT & 7 & & & & 2.8 & 0.008 & $2.9 \times 10^{3}$ & $2.0 \times 10^{-5}$ \\
\hline DESERT GAME RANGE & 4 & & & & 2.1 & 0.003 & $2.1 \times 10^{3}$ & $8.4 \times 10^{\circ}$ \\
\hline FUPNACE CREEK & 200 & & & & & 0.007 & $7 \times 10^{\circ}$ & $1.4 \times 10^{\circ}$ \\
\hline INDIAN SPAINGS & 1500 & 3400 & & 120 & 4.1 & 0.0057 & 3.8 & 5.7 \\
\hline LATHROP WELLS & 30 & 1800 & 0.68 & 550 & 4.9 & 0.018 & 2.7 & $8.1 \times 10^{2}$ \\
\hline LIDA JUNCTION & 8 & & 1.2 & & & & $1.2 \times 10^{3}$ & $9.6 \times 10^{\circ}$ \\
\hline MEDLIN'S RANCH & 4 & 1900 & 0.44 & 200 & 2.4 & & 2.3 & $9.2 \times 10^{-3}$ \\
\hline MT. CHARLESTON & 500 & & & & 2.1 & 0.0036 & $2.1 \times 10^{3}$ & $1.0 \times 10^{3}$ \\
\hline PAHAUMP & 15000 & & & & 2.5 & 0.0091 & $2.5 \times 10^{3}$ & $3.8 \times 10^{-2}$ \\
\hline PENOYER FARM & 20 & 1800 & 0.58 & 160 & & & 2.1 & $4.2 \times 10^{-2}$ \\
\hline RACHEL & 105 & 1800 & 0.48 & 150 & & & 2.1 & $2.2 \times 10^{-1}$ \\
\hline SARCOBATUS FLATS & 20 & 2400 & 1.6 & 100 & & & 2.5 & $5.0 \times 10^{2}$ \\
\hline SHOSHONE & 250 & & & & & 0.0056 & $5.6 \times 10^{6}$ & $1.4 \times 10^{\circ}$ \\
\hline S. NEV. CORR. CTR & 1400 & & & 90 & 3.2 & 0.0043 & $9.3 \times 10^{-2}$ & $1.3 \times 10^{-1}$ \\
\hline SPRINGDALE & 35 & 1600 & 1.6 & 420 & 3.3 & 0.0097 & 2.3 & $8.0 \times 10^{-2}$ \\
\hline STATELINE \& AREA & 127 & & & 260 & 3.0 & 0.0099 & 0.26 & $3.3 \times 10^{-2}$ \\
\hline TEMPIUTE & 2 & 1700 & 0.42 & 140 & & & 2.0 & $4.0 \times 10^{3}$ \\
\hline U.S. ECOLOGY & 35 & 1700 & 0.86 & 400 & 4.4 & 0.012 & 2.4 & $8.4 \times 10^{-2}$ \\
\hline
\end{tabular}

Emlssions calculated from survellance data, Included on EIS forms.

2. Emissions calculated from engineering

- Blank spaces represent locations farther than $80 \mathrm{~km}$ from the source for the column. 
Table 5. Effective Dose Equivalent Tabulation by I.ocation (cont'd)

\begin{tabular}{|c|c|c|c|c|c|c|}
\hline \multirow{2}{*}{$\begin{array}{l}\text { Total Poputation - } 21.750 \\
\text { Maximally Exposed Individual: } \\
0.0038 \text { mrem }\end{array}$} & \multicolumn{5}{|c|}{ Maxhmum Individual Dose Celculated for Each Roloses Polnt - $10^{3}$ mrem } & \multirow{3}{*}{$\begin{array}{l}\text { Toted Person-mrem: } \\
\qquad 0.012\end{array}$} \\
\hline & Area 12 & Penule Mesa & rucca fla & Area 5 & Marane & \\
\hline Location of Max: indian Springs & 3.4 & $1.6 \times 10^{3}$ & 0.91 & $4.8 \times 10^{0}$ & $2.0 \times 10^{-3}$ & \\
\hline
\end{tabular}

\section{Certification}

I certify under penalty of law that I have personally examined and am famillar with the information submitted herein and based on my inquiry of those individuals immediately responsible for obtaining the information, I believe that the submitted information is true, accurate and complete. I am aware that there are significant penalties for submitting false information including the possibility of fine and imprisonment. See 18 U.S.C. 1001.

Name: Nick C. Aquilina, Manager, Nevada Operations Office

Signature: $n$ wh Date: 6-2.4-9y 


\section{SECTION IV \\ ADDITIONAL INFORMATION}

\section{NEW CONSTRUCTIONMODIFICATION ACTIVITIES AT THE NTS}

No new construction or modification to existing permanent structures that emit radionuclides during normal operations were completed at the NTS in Calendar Year 1993.

\section{UNPLANNED RELEASES DURING THIS CALENDAR YEAR}

All releases during calendar year were operational. There were no detectable unplanned releases.

\section{SOURCES OF DIFFUSE OR FUGITIVE EMISSIONS}

These sources included evaporation from containment ponds of liquid effluents from $E, N, \& T$ tunnels, resuspension of ${ }^{230+240} \mathrm{Pu}$ from soil deposits on the NTS (plutonium was a negligible source of exposure to the offsite population), seepage of noble gases on Pahute Mesa, and seepage of tritium from packages buried at the RWMS in Area 5.

The EDE to the MEI was mostly due to the diffuse sources. The EDE from point sources was negligible. The methods used to determine the emissions from these diffuse sources are described in the appendices. 


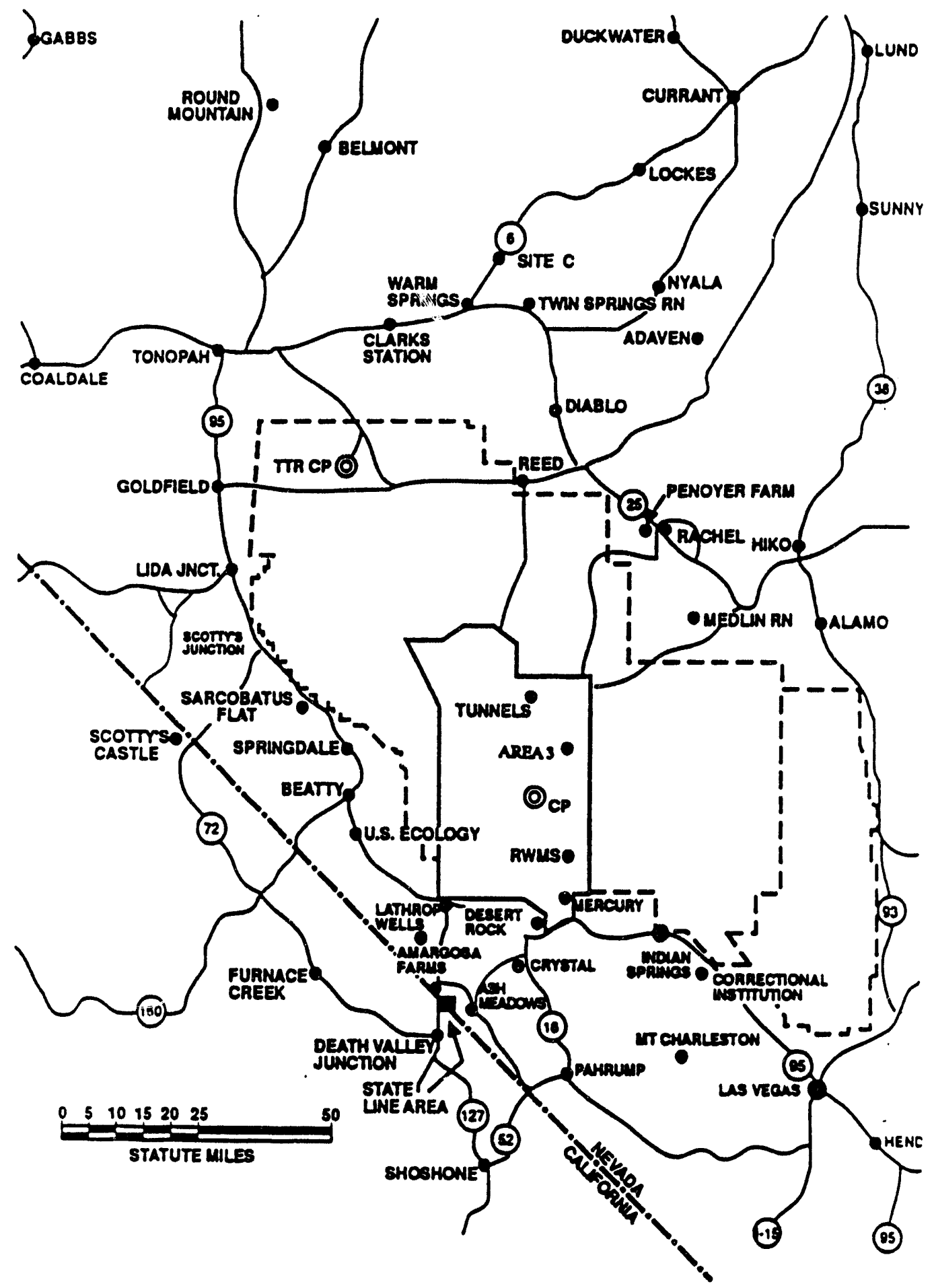

Figure 1. Map of the Area Around the NTS 


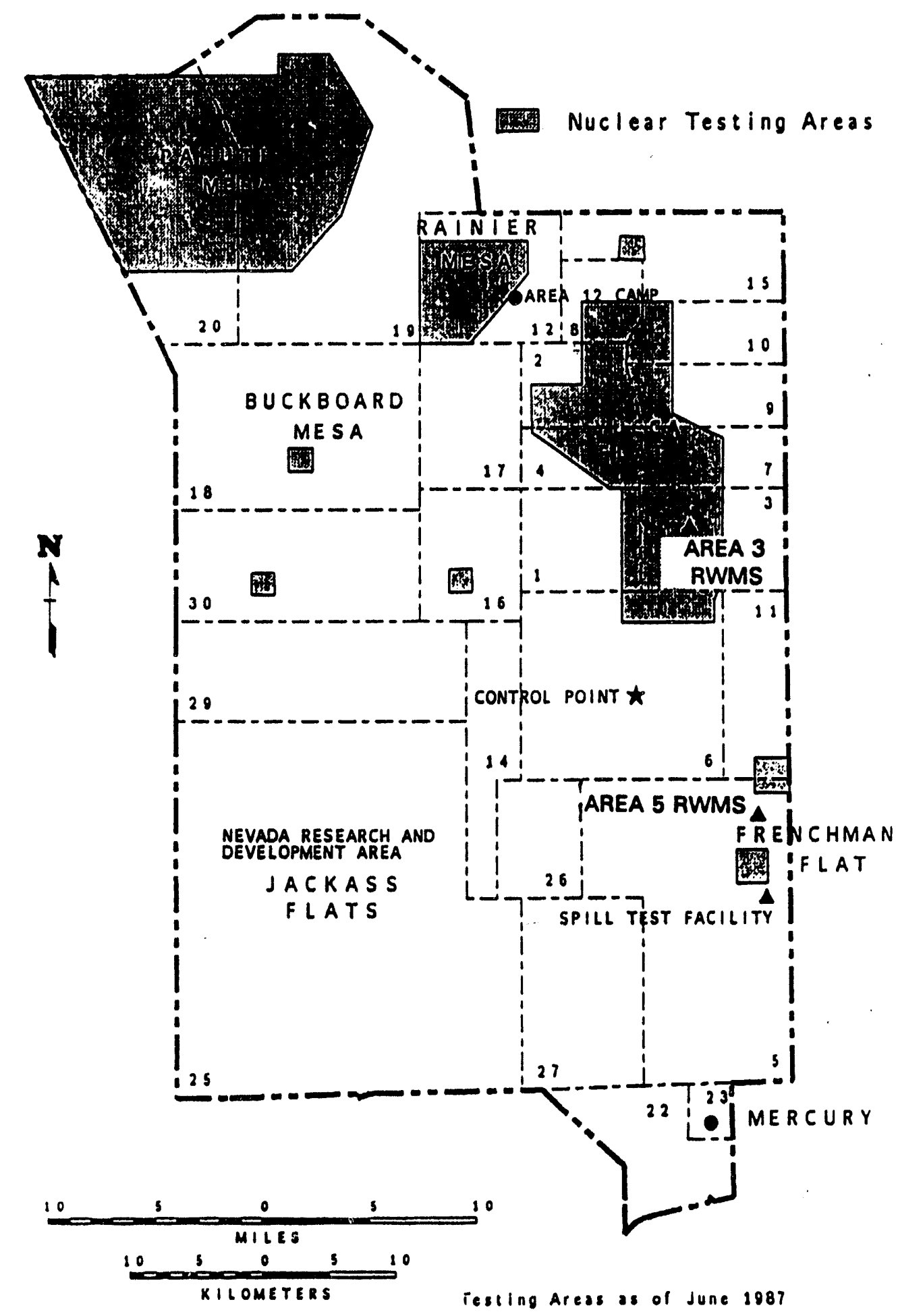

Figure 2. Nuclear Testing Areas on the Nevada Test Site 


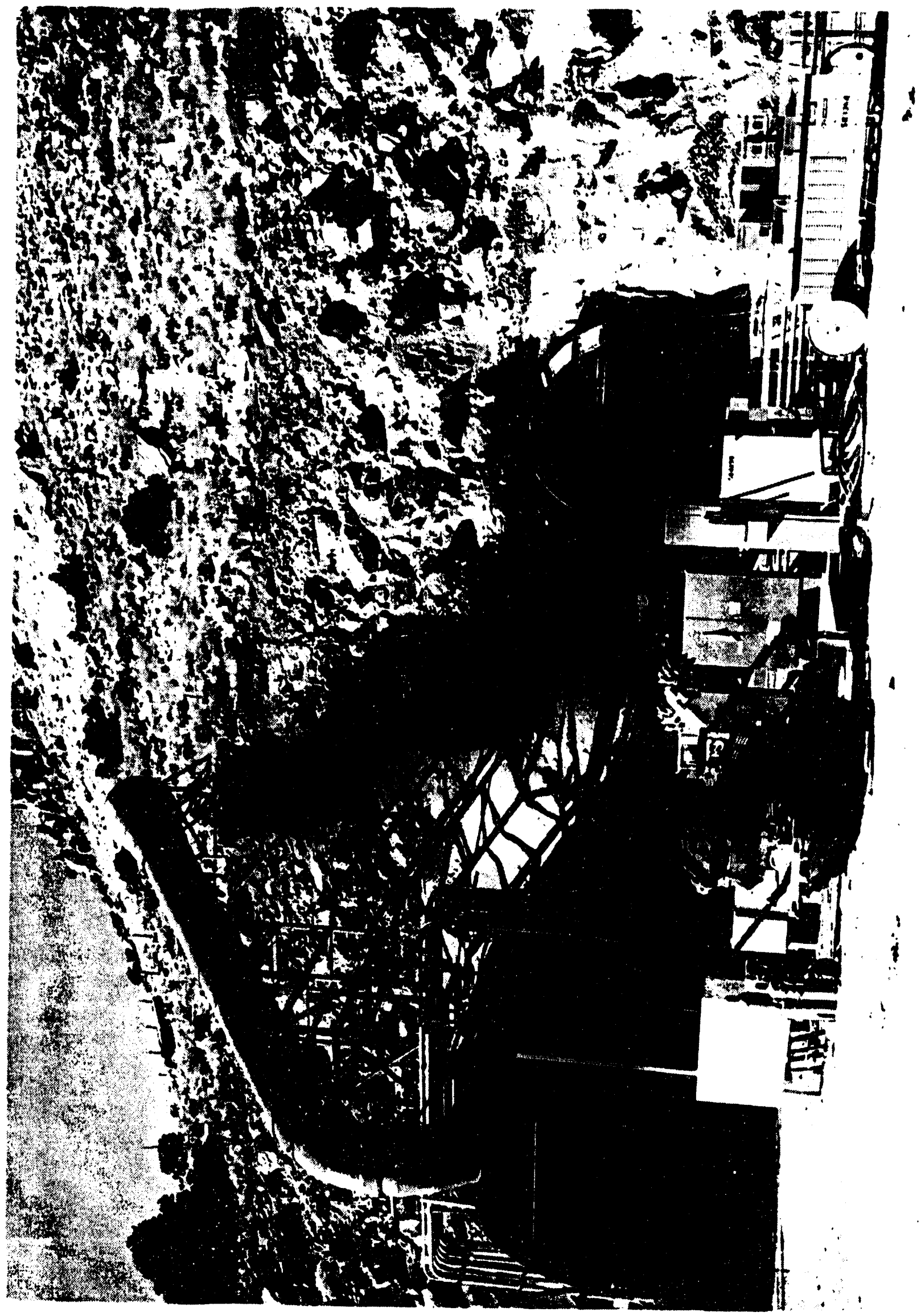

Figure 3. Photograph of a Tunnel Portal 


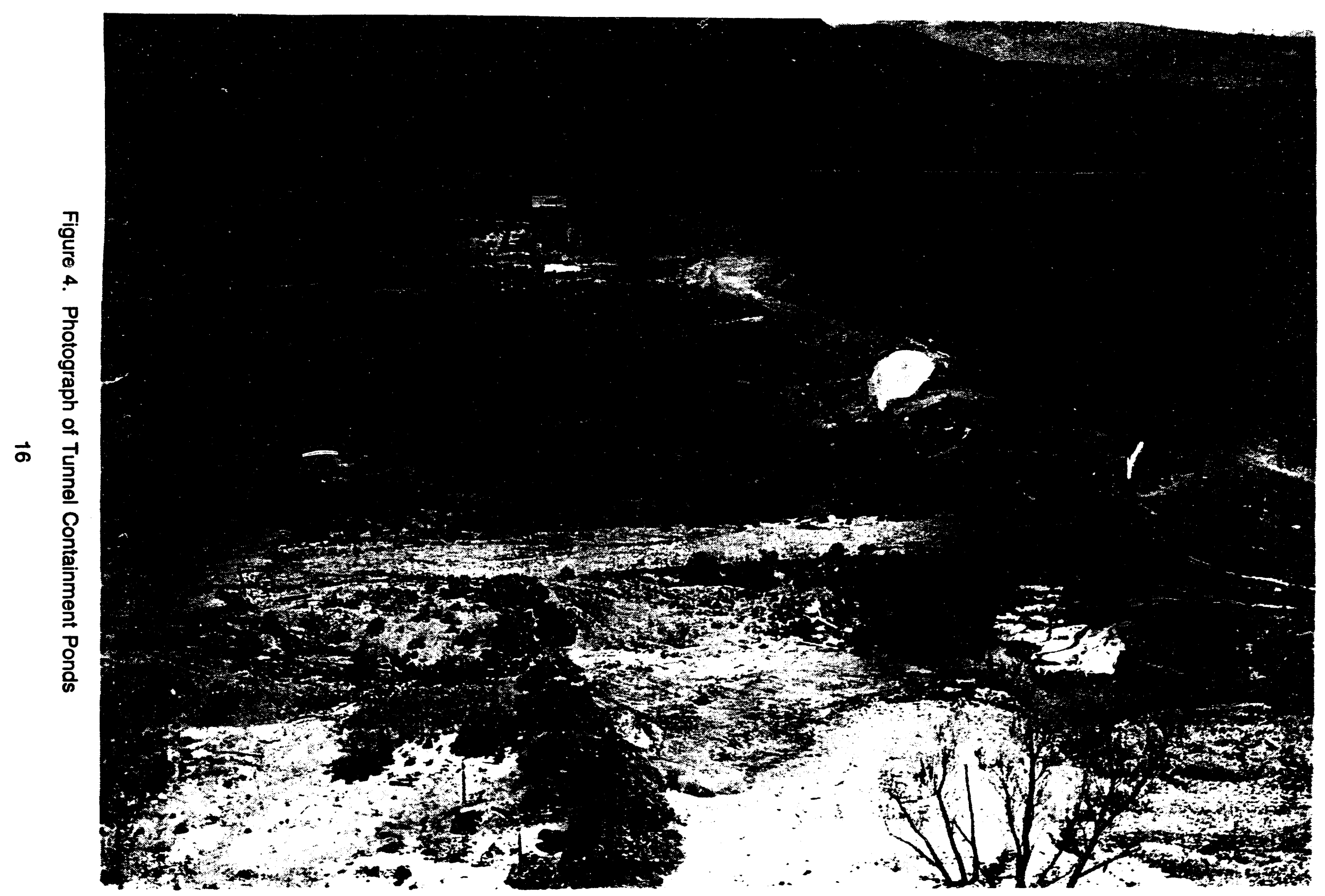




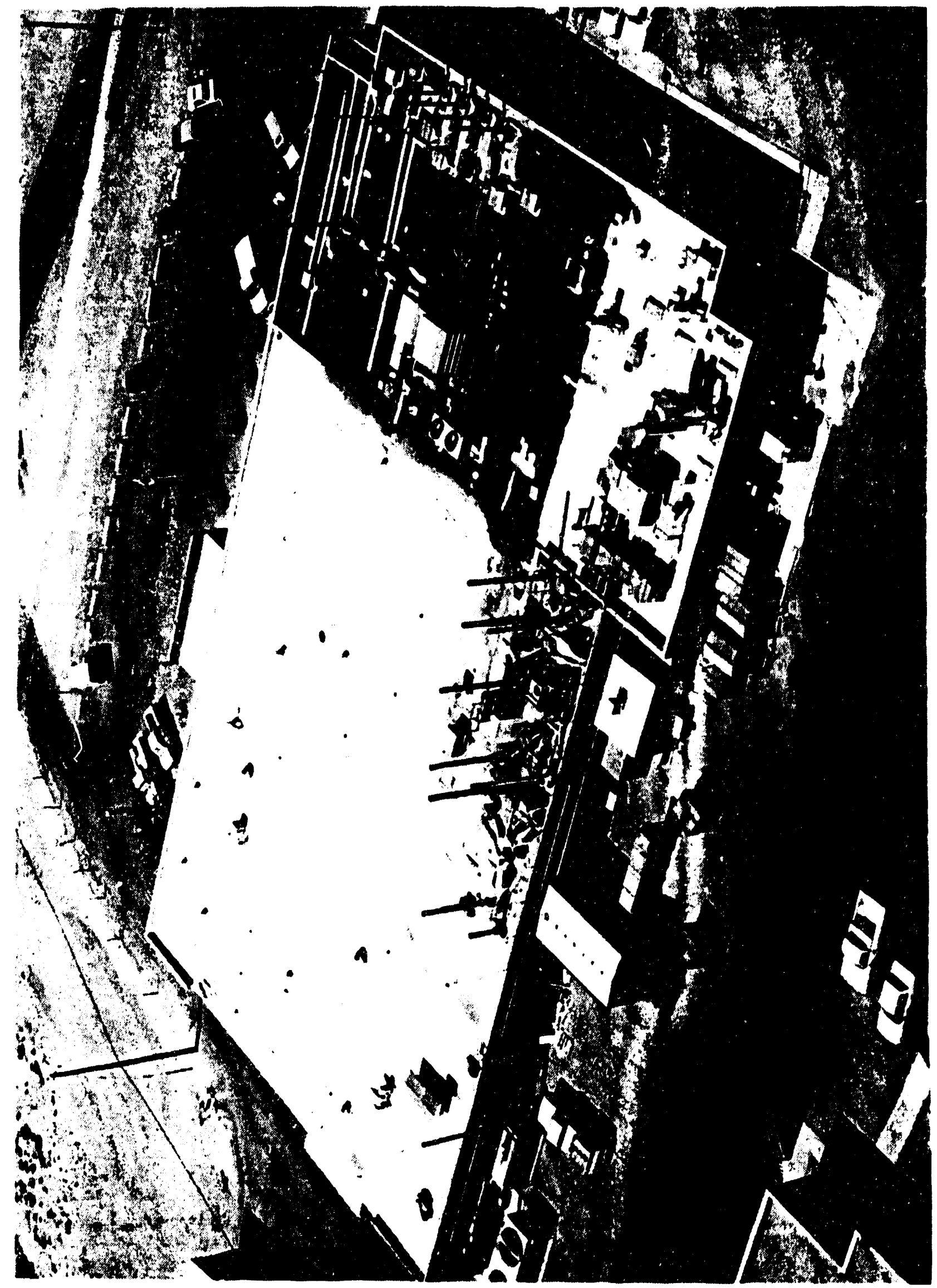

Figure 5. Photograph of the Building 650 Hood Ventilation Stacks Seen from Above 


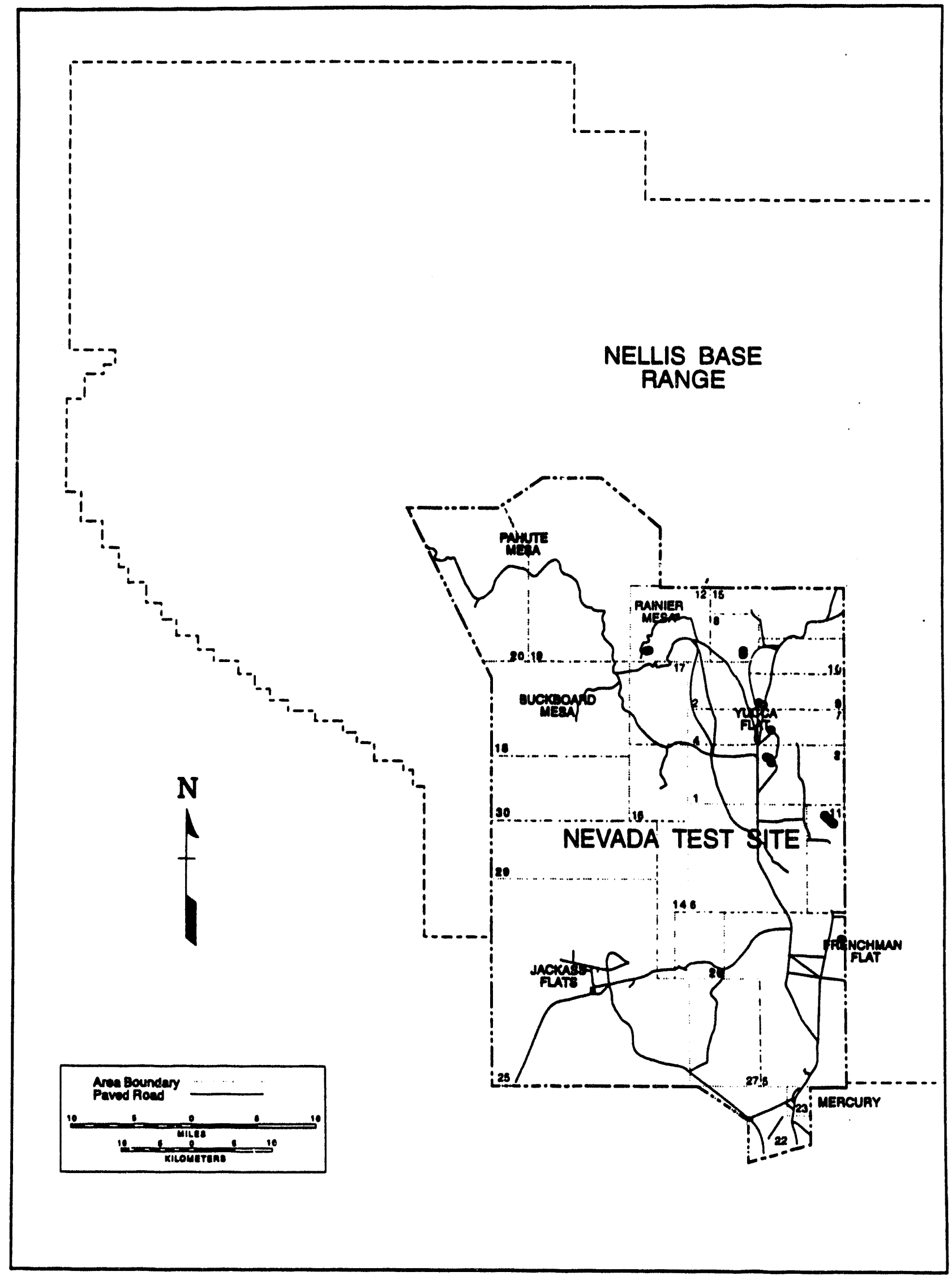

Figure 6. Locations of Nuclear Device Safety Tests $(0)$ on the NTS 
APPENDICES 


\section{APPENDIX A}

ANNUAL NATIONAL EMISSION STANDARDS FOR HAZARDOUS AIR POLLUTANTS

EMISSIONS REPORT

LAWRENCE LIVERMORE NATIONAL LABORATORY

NUCLEAR TEST OPERATIONS DEPARTMENT 


\section{INTRODUCTION}

Lawrence Livermore National Laboratory (LLNL) is one of the prime users of the Nevada Test Site (NTS). LLNL only performs effluent monitoring for its NTS projects. This plan includes the organizational structure and responsibility of LLNL, the present system of notification and reports, effluent monitoring programs with a brief discussion of any decisions made, quality assurance, dose calculation, and accuracy of effluent measurements.

Effluents may result because of an operation whose purpose was to sample the nuclear cavity region resulting from a nuclear explosion. The effluent quantity is small but the frequency of occurrence may be high.

\section{ORGANIZATIONAL STRUCTURE AND RESPONSIBILITY}

LLNL's Health, Safety, and Environmental Program is administered through the Associate Director for Nuclear Test-Experimental Science. Although authority is delegated to either the LLNL-Nuclear Test Operations Department (NTOD) head or the Test Director, execution of the program resides with LLNL-NTOD Environment, Safety and Health Group (ES\&H).

The line contact for effluent monitoring of LLNL programs at the NTS is the LLNL-NTOD ES\&H Group although responsibility may belong to the LLNL-NTOD Head or the LLNL Test Director.

\section{OPERATIONAL AREAS}

None of the activities for which the LLNL conducts effluent monitoring are permanent. Since the location of each underground nuclear explosion varies, an effluent monitoring system must be moved to that location. Effluent monitoring only takes place during the operation and at locations designated by DOE/NV as nuclear testing areas. The LLNL nuclear testing areas for underground testing in vertical shafts are Areas 2, 4, 8, 9, 10, 19, and 20. LLNL also has a permanent facility in Area 27 to perform device assemblies. Normally, no effluents result from these operations.

\section{EFFLUENTS}

The sources of effluent release from LLNL operations at the NTS, their probability of occurrence, and the range of activity encountered are listed in Table A.1. Additionally, a maximum potential postshot drilling release can be calculated, e.g., for this maximum potential release it is assumed that: (a) all containment apparatus has failed, (b) the means to shut in the hole do not exist, and (c) the concentration of chimney gas is homogenous. Calculations indicate that $10 \mu \mathrm{Ci} / \mathrm{mL} \times 10^{-6} \mathrm{Ci} / \mu \mathrm{Ci} \times 3.0 \times 10^{7} \mathrm{~mL}=300 \mathrm{Ci}$, of radioxenons may be released to the atmosphere. If it is additionally assumed that the ventline system does not work (therefore there is no filtering) some $40 \mathrm{mCi}$ of radioiodines are released. It is estimated that the first case has a probability of occurrence of less than $10^{-4}$ and the second case has a probability of occurrence of less than $10^{\circ}$.

It is estimated that this would contribute some $7 \times 10^{-4}$ mrem to an individual at $10 \mathrm{~km}$ from the release point.

The plans for monitoring this source are detailed in Attachment A.1. 
Table A.1. List of Radioactive Effluents and Probability of Occurrence

\begin{tabular}{|c|c|c|c|c|}
\hline \multirow[b]{2}{*}{ Operation } & \multicolumn{2}{|c|}{ Probability } & \multicolumn{2}{|c|}{ Effluent } \\
\hline & Type & of Occurrence & Isotopes & Activity Range \\
\hline Seep & Air & $<10^{-2}$ & $\begin{array}{l}{ }^{131 \mathrm{~m},}{ }^{133} \mathrm{Ke} \\
{ }^{\mathrm{Kr}}\end{array}$ & 5 to $1000 \mathrm{Ci}$ \\
\hline $\begin{array}{l}\text { Postshot: } \\
\text { Noble gases } \\
\text { lodine } \\
\text { Assembly } \\
\text { Postshot }\end{array}$ & $\begin{array}{l}\text { Air } \\
\text { Air } \\
\text { Air }\end{array}$ & $\begin{array}{l}0.4 \\
<0.1 \\
<10^{-7}\end{array}$ & $\begin{array}{l}{ }^{133,}{ }^{133 m,}{ }^{135} \mathrm{Xe} \\
{ }^{131},{ }^{133} \mathrm{I} \\
{ }^{3} \mathrm{H}\end{array}$ & $\begin{array}{l}0 \text { to } 100 \mathrm{Ci} \\
0 \text { to } 2.0 \mathrm{mCi} \\
0 \text { to } 100 \mathrm{Ci}\end{array}$ \\
\hline Sumps ${ }^{(a)}$ & Liquid & 1 & MFP & .01 to $5 \mathrm{mCi}$ \\
\hline Other & Unknown & Unknown & Unknown & Unknown \\
\hline
\end{tabular}

(a) For postshot operations after January 31, 1990, this liquid effluent stream was replaced by a containerizec' waste stream.

\section{EFFLUENT MONITORING PLAN}

The late-time seep of radioactive gases through the ground, driven by barometric changes, depends on the surface geology, yield, and barometric pressure. The probability of occurrence can be estimated before the event. No special monitoring is done because of continuous monitoring by the orisite Noble gas network, the low probability of occurrence, and minimal health impact. If a seep of this kind does occur, special monitoring will be requested when the source is identified.

Effluent monitoring of post-shot drilling activities is more complicated because its point of effluent release can vary in an unpredictable manner. For this reason, extensive monitoring is doria (see Attachment 1). The majority of releases are through the ventline, which is continuously monitored. The linear flow rate in the ventline is measured hourly. The ventline monitoring system and effluent calculation are explained in the references to Altachment A.1.

To preclude any liquid disposal in soil columns, the cellar effluent from post-shot drilling operations is containerized and either re-injected or disposed of in waste burial grounds.

Alarm criteria for post-shot monitoring are set at low levels so that steps to mitigate effluent release can be taken.

Monitoring for nonradioactive effluent during postshot drilling operations is limited to work place monitoring using portable instrumentation.

Work-place monitoring during device assembly operations, for both airborne alpha emitters and elemental tritium (when necessary), is continuous during device assembly operations. Alarm levels are set so as to preclude false alarms but provide adequate warning. The 
probability of any effluent is almost nonexistent. Therefore, no routine effluent monitoring program is conducted at the assembly facility.

LLNL does perform other experiments which may produce an effluent stream. When such a project is instituted, efforts to measure the effluent (radioactive and/or nonradioactive) with proper meteorological support are taken.

\section{QUALITY ASSURANCE}

The QA program for most effluent monitoring devices that LLNL-NTOD uses is administered through the contractors who provide those instruments. For example, the post-shot instrumentation is calibrated and maintained by the REECo HPD. LLNL provides general instructions conceming instrument calibration. Meteorological instruments are calibrated, fielded, and maintained by NOAA.

Performance validation of the post shot drilling effluent measuring instrument is as follows. The ventline monitor (only used for postshot operations) is checked with a sealed source of ${ }^{109} \mathrm{Cd}$ or ${ }^{133} \mathrm{Ba}$ (to simulate the low energy of ${ }^{133} \mathrm{Xe}$ ) in conditions similar to those seen during postshot operations. It is also checked with a ${ }^{60} \mathrm{Co}$ source and a pulser before each use and is frequently checked during use. Also, since a linear superposition of xenon isotopes is assumed, verification of xenon ratios is obtained from postshot gas samples.

\section{DOSE ESTIMATION AND EFFLUENT ERROR}

Calculations using CAP88-PC indicate that at 10km (a conservative estimate of distance to the maximally exposed individual) effluent releases of $95,000 \mathrm{Ci}$ of ${ }^{133} \mathrm{Xe}$ or $9.5 \mathrm{Ci}$ of ${ }^{131} \mathrm{I}$ or $2300 \mathrm{Ci}$ of ${ }^{3} \mathrm{H}$ would result in a receptor dose of 0.1 mrem and would require continuous monitoring. Using the maximum numbers in the effluent range given in Table A.1 for postshot activities and the release figures for CY92 (no releases), the resultant effective dose equivalents are listed in Table A.2.

Table A.2. Effective Dose Equivalents

$\begin{array}{lccc}\text { Operation } & \begin{array}{c}\text { Maximum } \\ \text { Isotope }\end{array} & \begin{array}{c}\text { CY92 Dose at 10km } \\ \text { at 10km }\end{array} \\ \text { Seep } & { }^{133} \mathrm{Xe} & 1 \times 10^{-3} \mathrm{mrem} & \begin{array}{c}\text { mrem } \\ \text { Postshot }\end{array} \\ { }^{133} \mathrm{Xe} & 1 \times 10^{-4} \mathrm{mrem} & 0 \mathrm{mrem} \\ \text { Postshot } & { }^{131} & 2 \times 10^{-5} \mathrm{mrem} & 0 \mathrm{mrem} \\ \text { Assembly } & { }^{3} \mathrm{H} & 4 \times 10^{-3} \mathrm{mrem} & 0 \mathrm{mrem}\end{array}$

Because LLNL-NTOD is only responsible for a portion of the NTS, DOENN only requires total activity determinations. Dose estimations are done as a part of work-place monitoring and are based on both measurements and external and internal dosimetry data. 
Special situations may arise in which dose estimations are made because of effluent releases. However, this estimate is only used for planning purposes. The final dose is based on all measurements made by DOENN's contractors and calculated by them.

The calculation of effluent is uncertain because of the type of release (diffuse or point), emanation point(s) of the release, assumptions made, and models used. Every effort is made to reduce this uncertainty by utilizing other onsite detection results. In some cases the releases can be easily defined geometrically and error could be as little as $\mathbf{3 0}$ percent. However, if Gaussian transport theory must be relied on, the result may be uncertain by a factor of ten. Effluent calculations done for postshot releases are less uncertain because transport theory is seldom used.

\section{NOTIFICATION AND REPORTS}

The procedure to be followed in notitying LLNL personnel is outlined in the NTS Health and Safety Manual. Notification of DOE personnel is also outlined in the NTS Health and Safety Manual.

It has been the policy of LLNL that upon notification of LLNL-NTOD ES\&H, a decision, based on the possible health, safety and environmental consequences of the incident, is made as to whether or not DOENV should be notified immediately. However, LLNL has been directed to notify DOENV immediately of instantaneous post-shot releases above 10 curies (per NTS-SOP-5402, "Radiation Release Surveillance - Notification Procedures," June, 1990). This immediate notification is followed by written documents to DOENV. These documents include:

Daily Reports Generated by the Resident Manager

Individual operational reports generated by LLNL-NTOD ES\&H within weeks after completion of the operation.

Completion reports of each fiscal year activity.

\section{Annual Radioactive Effluent and On-Site Discharge Data Reports.}

Final event reports (classified because of specific event information).

If an Occurrence Report (OR) or Off-Normal Report is required because of an effluent incident, the affected LLNL organization is responsible for investigating the occurrence and preparing the report. Both DOE/NV and DOE/SAN (San Francisco Operations Office) will receive copies of any OR.

The effluent calculations performed by LLNL-NTOD ES\&H results of which are reported, will include those elements required by DOENV to perform dose calculations as recommended in DOE Environmental Regulatory Guide, DOE/EH-0173T. Source term calculations shall describe the variables used, conversion factors, identify the source of data, describe the calculational method, and the effluent memo will be signed and dated. 


\section{ATTACHMENT A.A-1 \\ LAWRENCE LIVERMORE NATIONAL LABORATORY POSTSHOT DRILLING/EFFLUENT MONITORING}


Monitoring for effluent during postshot drilling operations is briefly described herein. The approach to effluent calculations is outlined and the reporting procedures discussed.

References for this document are internal to LLNL-NTOD. They are:

- Postshot Ventline Calculations, 1-6-82

- Postshot Ventline Release Calculations, 1-11-82

- Postshot Ventline Backup Calculations, 2-9-83

- Chemical Composition of Recent Drillstring and Tubing Gas Samples, 6-14-89

- Postshot Instrument Requirements, 2-5-90

- Radioactive Effluent Calculational Format, 1-29-90

- Procedure No. NTS-113; Occurrence Reporting System, 11-16-90

- Postshot Drilling Handbook, 1-19-84

- OSP-NC-2, Operational and Safety Procedure for Containment on Postshot Drilling Operations Conducted at the Nevada Test Site, 01-31-89

\section{GENERAL DESCRIPTION}

A brief discussion of postshot drilling points of effluent and the monitoring of those effluents follows:

The four main types of effluent, monitoring frequency, radioactive isotopes released and the expected range of activity are shown in Table A.A-1.

Table A.A-1. Effluent and Monitoring

\begin{tabular}{|c|c|c|c|c|c|}
\hline $\begin{array}{l}\text { Effluent } \\
\text { Point }\end{array}$ & $\frac{\text { Effluent }}{\text { Type }}$ & $\frac{\text { Monitor }}{\text { Type }}$ & Frequency & Isotopes & $\frac{\text { Range of }}{\text { Activity }}$ \\
\hline Ventline & Air & $\begin{array}{l}\text { Scintillation } \\
\text { Detector }\end{array}$ & Continuous & $\begin{array}{l}133,133 \mathrm{~m}, \\
{ }^{135} \mathrm{Xe}\end{array}$ & $0-100 \mathrm{Ci}$ \\
\hline Platform & Air & $\begin{array}{l}\text { Ionization } \\
\text { Detector }\end{array}$ & Continuous & $\begin{array}{c}133,133 m, \\
{ }^{135} \mathrm{Xe}_{\theta}\end{array}$ & $0-20 \mathrm{Ci}$ \\
\hline Platform & Air & Rig Filters & Continuous & 131,4331 & $0.2 \mathrm{mCi}$ \\
\hline Blooie Line & Liquid & Ion Detector & $\begin{array}{l}\text { Continuous } \\
\text { during } \\
\text { Operation }\end{array}$ & $\begin{array}{l}\text { Mixed } \\
\text { Fission } \\
\text { Products }\end{array}$ & $\begin{array}{c}0.01-5 \mathrm{mCi} \\
\text { (in sump) }\end{array}$ \\
\hline $\begin{array}{l}\text { Core } \\
\text { Trailer } \\
\text { Higrade } \\
\text { Shack }\end{array}$ & Air & Charcoal & $\begin{array}{l}\text { Continuous } \\
\text { during } \\
\text { Operation }\end{array}$ & $\begin{array}{l}\text { Mixed } \\
\text { Fission } \\
\text { Products }\end{array}$ & $<1 \mu \mathrm{Ci}$ \\
\hline
\end{tabular}


Release through ventline is the principal type of release encountered. The ventline is a $20^{\text {" }}$ O.D. steel pipe conducting air from the postshot drilling cellar through banks of filters to a point of release to the atmosphere (see Figure). Also, releases do occur on the rig platform primarily through the top of the drillstring (see Figure, reference 8). Minor releases of radioactivity may occur from handling of the core material in the core trailer or the highgrading (sample prep.) shack. Finally, a release of liquid radioactive effluent into the postshot drilling sump occurs as a result of emptying the contents of the postshot drilling cellar into the sump. This point of effluent has been eliminated.

The operation and function of each monitoring system used is described in the following:

\section{VENTLINE SYSTEM}

It is the purpose of this system to convey any airborne radioactive material not stopped by the drilling containment system away from the drilling area. This stream is diluted by mixing it with air. Particulates are removed by both gravity separation and high efficiency particulate air (HEPA) and charcoal filters. Two detectors monitor the ventline continuously and finally the treated stream is released to the atmosphere.

Pertinent Information:

Ventline: O.D. - 20"

thickness of steel -0.1012

horizontal run - approximately 200'

release height - approximately $\mathbf{1 5}^{\prime}$

Flow Rate: Linear - 900 to 1300 feet per minute

Volumetric - 1950 to 2850 CFM

Particulate Treatment: 10' vertical separator

HEPA Filter

Charcoal Filter - One foot in three banks

Detector: Primary - Nal Scintillator

Backup - Neher-White ionization chamber

The ventline detection system consists of a Nal scintillator primary detector and a Neher-White ionization chamber backup detector. It is the purpose of this ionization chamber to function at high intensities where the primary detector saturates and to act as a backup detector in case the primary detection system malfunctions. These detectors monitor radioactive effluent flow through the ventline before release to the atmosphere but after the filter bank (see Figure). Both systems have readouts, continuous strip chart recorders, and alarms in the core trailer.

Placement of the ventline detection system is predicated on three considerations, i.e., geometrical orientation, minimal interference (within operational constraints) and line source geometry.

Further requirements for performance checks and calibration are detailed in reference 5. 


\section{CELLAR DETECTOR}

The cellar detector is placed on top of the drilling stack in the postshot drilling cellar (see Figure). Its purpose is to provide the drilling engineer with information concerning radioactive gas concentration in the drillstring. Although not used directly in effluent monitoring, it does inform the driller of impending problems. Requirements for installation, performance checks, and calibration are set forth in reference 5.

\section{RIG MONITOR}

The rig monitor is a detection system placed on the rig platform (see Figure) to continuously monitor the platform exposure rate. Because its primary function is to warn working personnel, it has an audio alarm. It is also used to determine the duration of a platform release.

Requirements for installation, performance checks and calibration are shown in reference 5.

\section{BLOOIE LINE MONITOR}

The purpose of the bloole line monitor is to determine gross radiation levels of drillback returns passing through the blooie line. This detector monitors continuously and is recorded on a strip chart in the core trailer. The detector is placed on the blooie line near the blooie line's entrance into the sump (see Figure). Requirements for installation, performance checks, and calibration are enumerated in reference 5.

\section{DRILL RIG FILTER SAMPLERS}

Drill Rig filter samplers provide information concerning platform operational conditions. They are located on the platform in the primary working areas (see Figure). The 4-inch diameter filters consist of a paper prefilter and a charcoal filter which are changed every 8 hours after approximately $50 \mathrm{~m}^{3}$ of air pass through the filters. After removal, the rig filters are counted using gamma spectroscopy to provide after-the-fact isotopic information.

Because of the low sample collection efficiency for Xenon gases, the drill rig filter samples are only used to provide effluent information for platform lodine releases.

\section{OTHER}

Because of the variability of postshot drilling operations and many operational constraints, it is not always possible to set up permanent detection systems. However, those points that require monitoring are monitored by the use of portable instruments, high volume filter samples or specially setup sampling equipment.

Platform releases of Xenon gases and evolving gas from core material are the two main types of effluent which are quantified by means of other samplers. Special monitoring equipment may be used for th sse operations in which either new points of effluent are created or sensitivity to a particular isotope needs to be enhanced.

In addition, grab samples may be collected to aid area control or to supplement effluent monitoring. 
The above only addresses radioactive effluent. The only source of non-radioactive effluent is core material (an analysis of the cavity air in postshot drilling gas samples is provided, see reference 4). Any waste produced by the postshot drilling operations is sampled and analyzed for non-radioactive constituents, e.g., lead.

\section{POST OPERATION}

Upon completion of a postshot drilling operation, two types of samples are taken. They are cellar integrity samples to ascertain radioactive concentrations in the postshot drilling cellar and grab samples to determine the extent of environmental effect of the operation. Integrity samples are changed every 24 hours and the paper filter and charcoal filter are sent to the REECo Health Physics Department Laboratory for lsotopic analysis. The flow rate of the integrity sampler is approximately $10 \mathrm{cfm}$.

Grab samples are taken when required and the analysis depends on the reasoning for sampling.

\section{EFFLUENT CALCULATIONS}

This section briefly describes the effluent calculation used by LLNL for postshot drilling. The calculational format needs to be both formal and descriptive (see reference 6).

Effluent calculations for a release through the ventline use three main assumptions. A line source geometry is assumed and it is assumed that the detector signal is a linear superposition of ${ }^{139} \mathrm{Xe},{ }^{133 \mathrm{~m}} \mathrm{Xe}$, and ${ }^{136} \mathrm{Xe}$. It is further assumed that the ratios of isotopes can be obtained from abundance verses time curves for the fissioning of ${ }^{239} \mathrm{Pu}$. A more detailed description is given in references 1,2 , and 3.

Because ventline release calculations depend linearly on the volumetric flow rate, frequent and accurate measurements of the ventline flow rate are made (see reference 5).

Effluent releases at points other than the ventline must rely on detection systems that are not optimized for the purpose. Portable instruments may give very good information for a point in time, but give little or no time information whereas stationary instruments provide fairly reliable time information but very inaccurate intensity information. A combination of the two may give release information accurate to within $50 \%$. Information from the onsite environmental surveillance network may provide an upper limit to the releases.

An exception to the above is a platform iodine release. The point of release is usually known and all that is required is to relate the total quantity on the filter to the point of release. 


\section{LEGEND}

1. Drill Rig

2. Postshot Cellar

3. Rig Filters

4. Core Trailer

5. High Grade Shack

6. Sump

7. Blooie Line and Detector

8. Ventline

9. Access Control Fence

10. Filter Bank

11. Ventline Detector

12. Cyclone Blower

13. Ventline Exhaust

14. Abandonment Valve

15. Blow-Out Preventer

16. Rotating Head

17. Drill Pipe

18. Regan Head

19. Cellar Detector

20. Mast

21. Control Panel

22. Platform Detector

23. Cellar Containment Cover
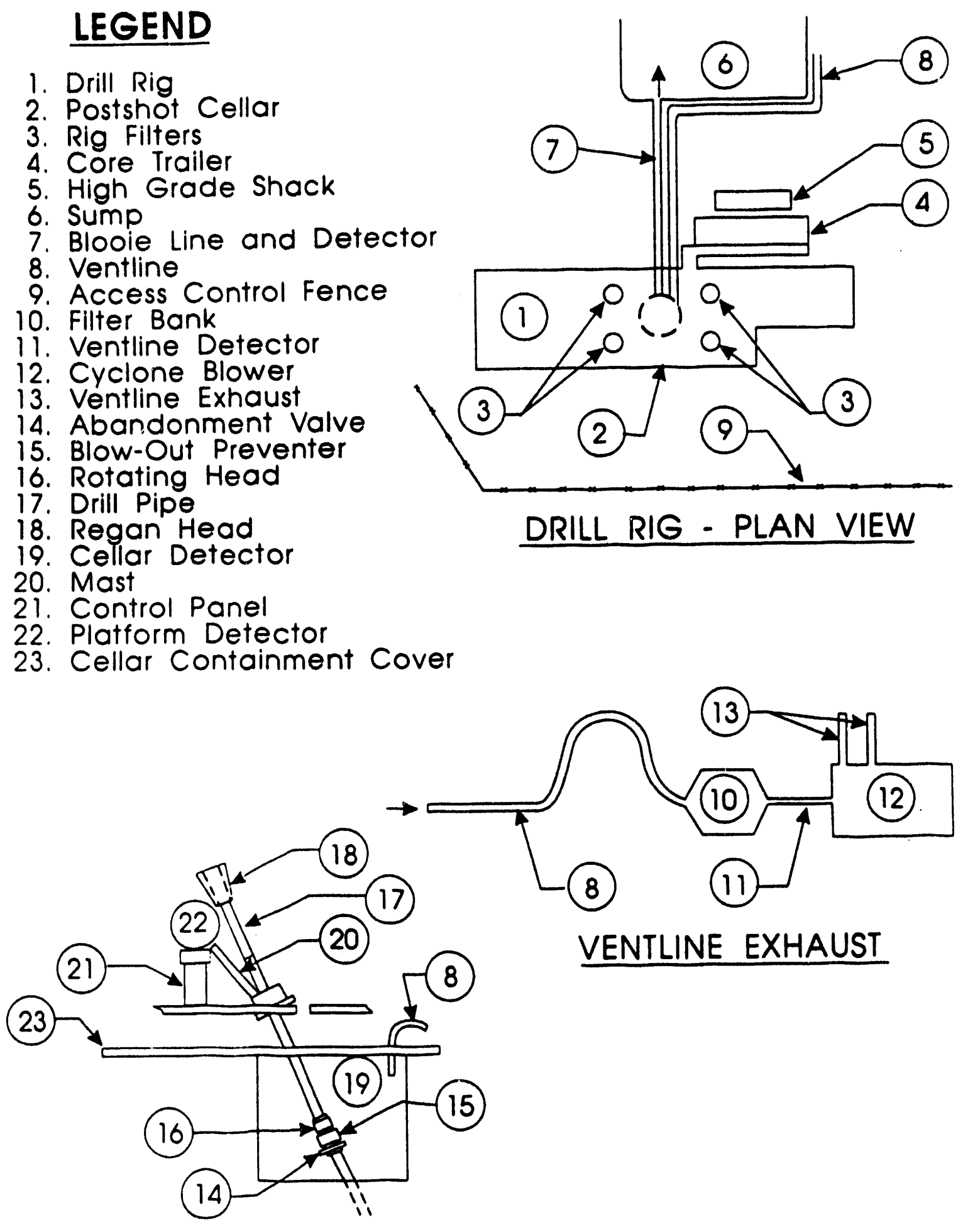

POSTSHOT DRILLING CELLAR

Figure A-A.1. LLNL Containment Hardware 


\section{APPENDIX B}

ANNUAL NATIONAL EMISSION STANDARDS FOR HAZARDOUS AIR POLLUTANTS

EMISSIONS REPORT

LOS ALAMOS NATIONAL LABORATORY

GROUP HS-12 FIELD TEST SECTION 


\section{POTENTIAL EMISSIONS}

\section{WEAPONS TEST AREAS - DRILLBACK}

Potential for the release of radioactive material to the atmosphere during normal operations. There exists the potential to release volatile fission products, notably noble gasses and lodine during the operations required to recover solid samples of the fission product debris. The potential exists to release an estimated 10 curies of ${ }^{130} \mathrm{Xe}$ and 0.5 millicuries ${ }^{\circ}{ }^{191} \mathrm{I}$ during the operation.

- The 10 curie estimate is felt to represent an upper limit for the distribution of possible releases. The estimate is derived from LLNL and LANL experience with 16 releases from drillback operations that have occurred over the past few years. These have ranged from 24 microcuries to 14 curies of xenon. This is felt to probably represent, to one significant figure, the upper end of the spread of estimates. It is further estimated that about 4 curies of xenon were seen in the containment system during the BEXAR cementback in 1991, and about one half curie was released.

- The method of using actual experience is felt to be superior to a theoretical treatment of the subject. The LANL documentation of release includes the value for xenon. This element is held up by the cleanup system, but not retained. The values for release would be the same even if the cleanup system was not operational. The lodine value is the theoretical value, assuming the mix as reported in LA-3420-MS, "Analysis of Underground Weapon Test Effluent Samples," for the amount of xenon seen, and a delay time of about 1 wook.

- From Yucca Flat, the Maximally Exposed Individual lives in Crystal, at a distance of $52 \mathrm{~km}$ due south. Assuming a release of $10 \mathrm{Cl}$ of ${ }^{130} \mathrm{Xe}$ and $0.5 \mathrm{Cl}$ of ${ }^{131} \mathrm{I}$, the Effective Dose Equivalent for all radionuclides and all pathways would be $1.7 \times 10^{-6} \mathrm{mrem}$.

Based on these data, no effluent monitoring is required to meet the standards. LANL will continue to monitor this potential source of emissions as a matter of Best Management Practices for Health Physics. The information generated is of great interest to both the resident Health Physicist and the drilling engineers.

\section{BUILDING 701 RADIO-ANALYTICAL LABOBATORY}

Potential for the emission of xenon, iodine and tritium. Maximum emissions are estimated to be 40 millicuries of ${ }^{133} X_{\theta}, 2$ microcuries of ${ }^{131} \mathrm{l}$, and 500 microcuries of tritium.

- The lodine and xenon values are based on sample measurements during the BEXAR cementback, and estimated possible numbers of samples. For the BEXAR cementback there were approximately 14 sets of samples with four samples containing ${ }^{131} \mathrm{I}$ in each set. The average concentration was of the order of $10^{-10} \mathrm{CVm}^{3}$, with a sample volume of $50 \mathrm{~m}^{3}$. This implies an average value of $5 \times 10^{-0} \mathrm{Cl}$ per sample or $0.3 \mu \mathrm{Ci}$ for the whole operation. Assuming 6 such operations per year, the total inyentory would be $2 \mu \mathrm{Ci}$. No credit is taken for the fact that this iodine is very securely held on the charcoal cartridges on which it is collected: the whole amount is treated as a gas. For calibration purposes, ${ }^{133} \mathrm{Xe}$ is purchased in glass vials containing up to $20 \mathrm{mCl}$ each. Accidents could result in a couple of these vials being broken during the year thus releasing the about $40 \mathrm{mCi}$. Tritium is received at the laboratory as HTO in $500 \mathrm{~mL}$ bottles. Concentrations as high as 50,000 $\mathrm{pCl} / \mathrm{mL}$ have been measured ( $25 \mu \mathrm{Ci}$ per sample). It is assumed that no more than 20 of 
these would be on hand in the Laboratory during any time during the year. The total inventory would then be no more than $500 \mu \mathrm{Ci}$ at any time.

- This method of estimating release from the laboratory is in compliance with Appendix D, with very adequate margins of conservatism.

- From Mercury, the Maximally Exposed Individual lives in Pahrump, at a distance of $51 \mathrm{~km}$ due south. Using the maximum activity for the radiolsotopes in the Laboratory, the Effective Dose Equivalent for all radionuclides and all pathways would be $8 \times 10^{-6} \mathrm{mrem}$. This is well below the threshold requiring effluent monitoring.

\section{WEAPONS AREA - EVENT TIME}

Potential for accidental release of radioactive material either as a "prompt massive venting" or as a "seep release".

\section{ASSEMBLYY AREA}

Potential for the accidental release of radioactive material to the atmosphere. There is no potential for atmospheric release aside from an accident.

\section{POTENTIAL SOURCES}

Potential sources of radioactive effluents are: (a) Weapons Test Area - Zero Time, accidental releases only, (b) Weapons Test Area - Drillback Operations, operational as well as accidental releases, (c) Assembly Area, accidental releases only, and (d) Building 701 Analytical Laboratory, accidental as well as operational releases.

\section{SUMMABIZED DESCRIPTION OF DRILLBACK RESPONSIBIIITIES AND PROCEDURES}

The Test Group Director is responsible for all Los Alamos National Laboratory operations on the NTS, including drillbacks. This includes HS\&E responsibility for the area for which that responsibility has been specifically transferred. The specific responsibility for the preparation, setup, operation, and cleanup of the drillback location is delegated to a senior drilling engineer in LANL Field Engineering Group, J-6. Radiological safety responsibility is delegated to a senior health physicist in the LANL Radiation Protection Group, HS-12. The Field Test Sectier Leader, in HS-12, is responsible for the collection, reduction, and interpretation of all health and effluent data.

A detailed description of the LANL Post Shot Drilling Operations is given in "Los Alamos National Laboratory Post Shot Drillback Operations and Responsibilities, March 1990 Edition. This summary is extracted from that document. The containment system consists of the blowout preventer (BOP) located in the cellar under the drillig, the recirculation trailer (housing the blowers and valving to generate and direct air flow through the containment system), the hoses connecting the BOP to the containment trailer, and the containment control panel used to operate the containment system. Once the surface casing is installed and cemented in place (cement pumped down the surface casing and forced up around the casing to create the cellar floor), the BOP is installed, and the containment trailer and recirculation system are made operational and connected to the BOP. The annulus pressure air line, used to blow air from the cellar down the annulus after the loss of mud circulation, and the test line, used during testing of the BOP and to monitor the gas in the annulus after circulation is lost, are connected at appropriate points on the BOP and the recirculation system. A schematic of the containment system from the published procedures is attached. 
The Rad Lab trailer radiation and explosive gas detection and alarm systems are calibrated and connected to the appropriate sampling points on the containment system (the annulus pressure line to sample cellar air and the test line to sample annulus air). The details of these procedures are included in a collection of documents for specific parts of the operation.

The containment equipment test procedure (pressure check) is completed by the J-6 engineer as described in the procedures. This procedure checks the system for leaks in various configurations at pressures of 5 and 25 psig. The operation of the valves and indicators is checked.

Drilling commences only after the above setups and checks have been successfully completed. Initially, drilling fluid is returned to the surface through the mud flowline. Cuttings and debris are removed at the shaker table and the mud is recirculated downhole. During this phase of drilling, air is drawn from the cellar and exhausted up the mast through the containment system. This air is monitored for radioactive and explosive gasses by the equipment in the Rad Lab trailer, even though the path to the cavity is effectively blocked by a standing column of drilling fluid in the hole. Air samples are taken at four points on the drillig floor and just outside the cellar door and are changed every eight hours to correspond to the workers' shifts.

When the drilling fluid begins to flow into fissures and voids in the formation, the fluid is no longer circulated back to the surface (loss of circulation). After loss of circulation, the mud retum line is closed and cellar air is now blown down the annulus through the containment system annulus pressure air line. Radioactive and explosive gasses are now monitored both in the recirculation air and in the annulus.

Once the total required depth has been reached, drilling is discontinued and sidewall samples are collected through a sampling port in the drill string. Small amounts of drilling fluid may be pumped down the drill pipe to help control gas flow up the inside of the pipe. Air continues to be monitored and blown down the annulus through the containment system. Additional air samples are collected in the core sampling and handling areas adjacent to the rig.

When sampling is completed, the drill pipe is removed from the hole and the ball valve in the BOP is closed. The containment recirculation system and the Rad Lab monitoring systems are shut down, and the air sampling effort is reduced to a single sampler just outside the cellar door. The filters on this sampler are changed once a day until operations are resumed at the location.

After post shot drilling and sampling activities are completed, the hole is cemented to the surface. During this operation drillig floor sampling is resumed as is monitoring through the Rad Lab Trailer. The containment recirculation system is activated and cellar air is blown downhole through the annulus pressure air line. The ball valve is opened and a bridge plug is run into the hole and set below a predefined minimum depth. The hole is then cemented to the surface in stages. At some point in this process, air can no longer be blown down hole, and the recirculation system is secured. Once the cement has been tagged at a satisfactory depth, the hole is considered secured and the BOP is removed. 


\section{MONITORING EQUIPMENT AND PROCEDURES}

The Los Alamos National Laboratory hardware is designed to completely contain all chimney gas. During active drilling and sampling operations, air is drawn from the cellar, sampled, and retumed to the annulus below the containment hardware. This provides a column of air moving down the annulus to keep gas from the cavity from reaching the containment hardware. This method of containment is used after drilling fluid no longer retums to the surface (loss of circulation), and before the hole is closed by either closing the ball valve or by the use of sufficient cement during the cementback. Figure B.1 shows the hardware configured to contain the gasses.

When the air from the cellar cannot be blown down hole, it is exhausted up the mast. This happens before loss of circulation and after the hole is plugged with cement. The valve shown in Figure B.1 can be rotated to cause this switch.

As long as the system is running, a sample of the air is analyzed for the presence of radionuclides emitting gamma rays with energies above $60 \mathrm{keV}$. The characteristic gamma ray of ${ }^{130} \mathrm{Xe}$ is about $80 \mathrm{keV}$. The system has been calibrated in terms of total ${ }^{133} \mathrm{Xe}_{\theta}$ in the system. A few vials of National Institute of Standards and Technology (NIST) traceable ${ }^{133} \mathrm{Xe}$ were obtained from DuPont/New England Nuclear. These vials were used to determine the activity in about 25 other vials that were released into the system under normal operating conditions, and the response of the detection system was thus calibrated. The few trials precludes a detailed treatment of error, but the data available suggest that the precision is probably better than a factor of 2. In the event chimney gas is detected by the system, the procedures set forth in "Field Test Health Physics Section Detailed Procedure for Estimation of Activity in the Containment System" are used. While the system is in the containment mode, the result is simply the ${ }^{133} \mathrm{Xe}_{e}$ captured. When the system is in the mast exhaust mode, the result is the release of ${ }^{133} \mathrm{Xe}$. The release of ${ }^{131} \mathrm{I}$ is then inferred from the ${ }^{133} \mathrm{Xe}$ and the age of the gasses using the data presented in LA-3420-MS, Analysis of Underground Weapons Test Effluent Samples.

In the event that chimney gas is detected on the air samples collected on the platform, the procedures set forth in "Field Test Health Physics Section Detailed Procedure for Estimation of Release Using Health Samples" are used. This technique is based on the experience at the LOCKNEY drillback. Chimney gas was exhausted into the cellar after having been through the containment system. This allowed for the measurement of the source using the calibrated system. The measured concentration of iodine on all sample heads and the length of the sampling period are used to estimate the release, using LOCKNEY as an analogue.

The measured ${ }^{131}$ I values are used since the samplers collect iodine almost quantitatively. Since this is a single point "calibration" of the technique a detailed treatment of error is not possible. The results of applying the technique to other events indicate that the precision is probably better than an order of magnitude, and is probably close to a factor of three. The data in LA-3420-MS are again used to infer the ${ }^{133} \mathrm{Xe}$.

When the cementback does not directly follow the drillback, the containment hardware is closed, the recirculating air shut off, and a single sample is collected in the cellar. This sample verifies that the hole is properly closed. If chimney gas is detected on this sample an estimate of release is generated, again using LOCKNEY as an analogue. The technique is given in "Field Test Health Physics Section Detailed Procedure for Interpretation of Cellar Samples". Since this is a single point "calibration" of the technique a detailed treatment of 


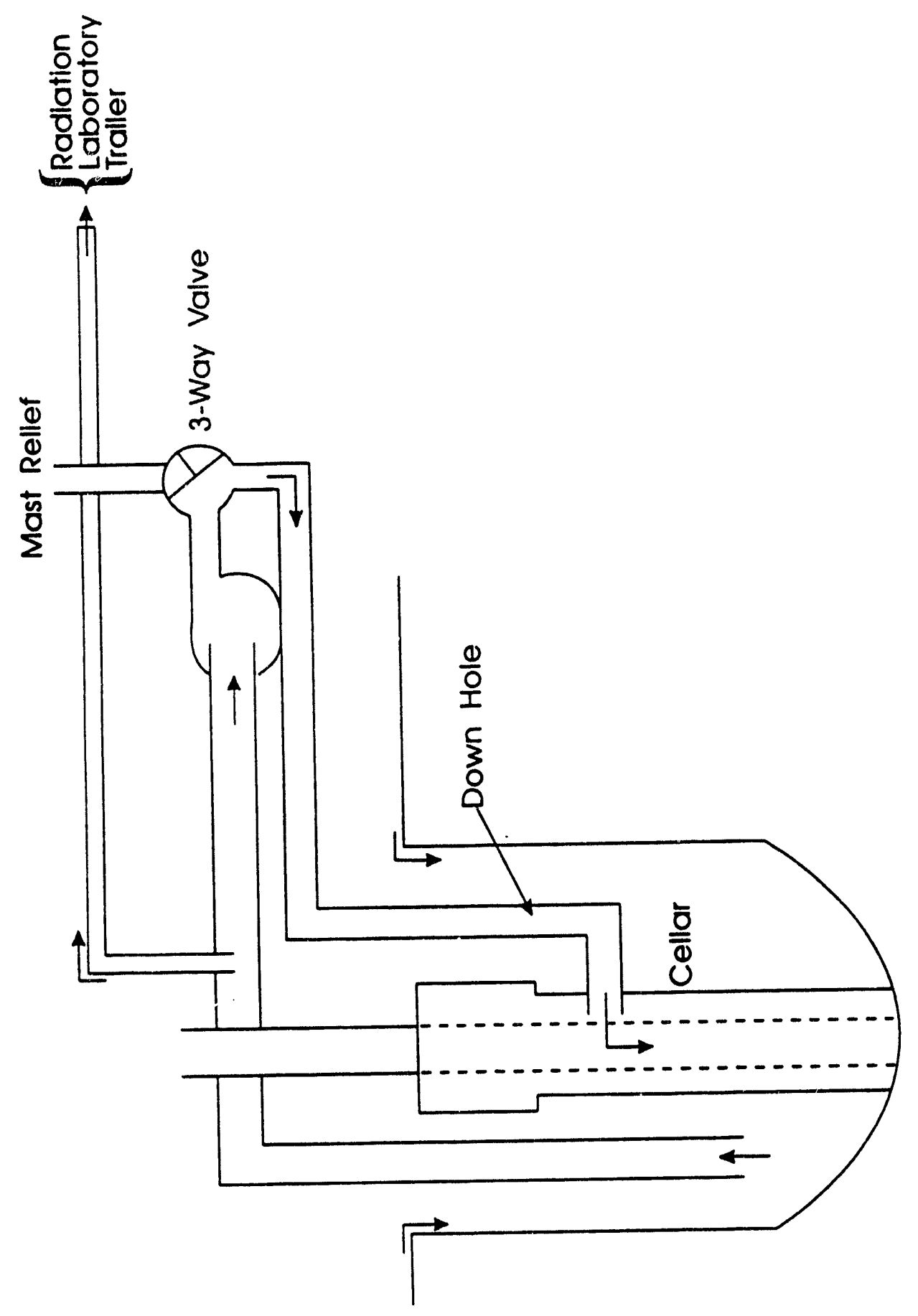

Figure B.1. LANL Containment Hardware 
error is not possible. The precision of this technique is probably not much better than an order of magnitude, depending on the material detected by the sampler. The data in LA-3420-MS are again used to infer the composition.

\section{OTHER SOURCES}

There were no other sources.

\section{INVENTORY OF RADIONUCLIDES}

For 1993 the inventory of tritium, lodine and xenon in Building 701 was calculated as:

Tritium $5 \times 10^{-05}$ curies (NIST Standard) (All other samples trivial). lodine $1 \times 10^{-07}$ curies; Calculated from reported concentrations and volumes.

Xenon $4 \times 10^{-01}$ curies; Xenon standard gas used for Radiological Laboratory calibration.

\section{REPORTS}

HS-12, NTS/Offsite Operations Section is responsible for the collection and interpretation of all health and effluent data. The results generated during drillbacks and cementbacks are reported to the Test Group Director at various times and in various forms during the course of the operations. At the completion of the operation, a report entitled, "Release and Health Sample Documentation for (EVENT NAME)" from HS-12 to the J Division Leader is generated that combines and summarizes the results generated. This report is distributed to the HS Division Office, the Test Group Director(s), the HS-12 Group Office, and the J-6 Group Office. These data are distributed as "Activity Released from (EVENT), Final Report" by the LANL J Division Office to Nuclear Test Organization, Test Controller, Attention: Chief, OMB CP-1 with copies to: NVOO Manager, LANLADNWT, and LANLJ-DO.

Annually, all results are combined and reported as "Effluent Information (EIS) and On-site Discharge Information (ODIS) for CY-(year) to Waste Reduction Operations, EG\&G Idaho, Inc. Copies of this report are sent to: DOENV/ERWM, REECO/HPD, LANLHS-DO, LANL/HS-12, LANLEM-8, AND LANLJ-DO. 


\section{APPENDIX C}

EMISSIONS DATA AND MONITORING PROCEDURES FOR THE DEFENSE NUCLEAR AGENCY COMPLIANCE WITH THE NATIONAL EMISSION STANDARDS FOR HAZARDOUS AIR POLLUTANTS (NESHAP) 


\section{INTRODUCTION}

The weapons effects testing program conducted in NTS tunnels has the possibility of releasing some radioactive effluent into the tunnel ventilation system during several of the operations associated with executing a test and the subsequent tunnel reentry activities. The tunnel ponds and Test Support Compound may also release radioactive effluent to the atmosphere.

Modeling of these potential sources using CAP88-PC indicates that the dose to the maximally exposed individual (MEI) in the off-site area is well below $0.1 \mathrm{mrem} / \mathrm{year}$; thus these sources are classified as small releases and the release point does not need to be continuously monitored. However, periodic measurements must be made to verify the small releases. These confirmatory measurements do not necessarily need to be made at the point of discharge.

\section{ORGANIZATION}

Figure C.1 shows the DNA organization at the Nevada Test Site, and identifies the FCNV personnel responsible for each operation. The Chief, Field Command Nevada Operations (FCNV) maintains overall responsibility for underground nuclear weapons effects tests conducted by DNA. However, FCNV personnel depend on the expertise provided by the DNA health physics advisor for identifying and estimating radionuclides released during each operation. Table C. 1 lists the FCNV divisions responsible for each operation.

Table C.1. Operational Responsibilities by FCNV Division

\section{NVCE}

Preparation of the Test Bed

Initial Tunnel Reentries and

Purging of the Tunnel

Data Recovery

Removal of Containment Plugs

Experiment Recoveries, Instrumentation Removal and

Cleanup Activities

Gas Sampling Operations

Reentry Mining

Assessment of Mechanical

Closure Performance

Atmospheric Pumping

Tunnel Ponds
NVTO

Device Detonation

Test Support Compound 


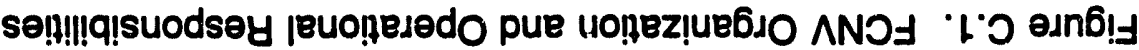

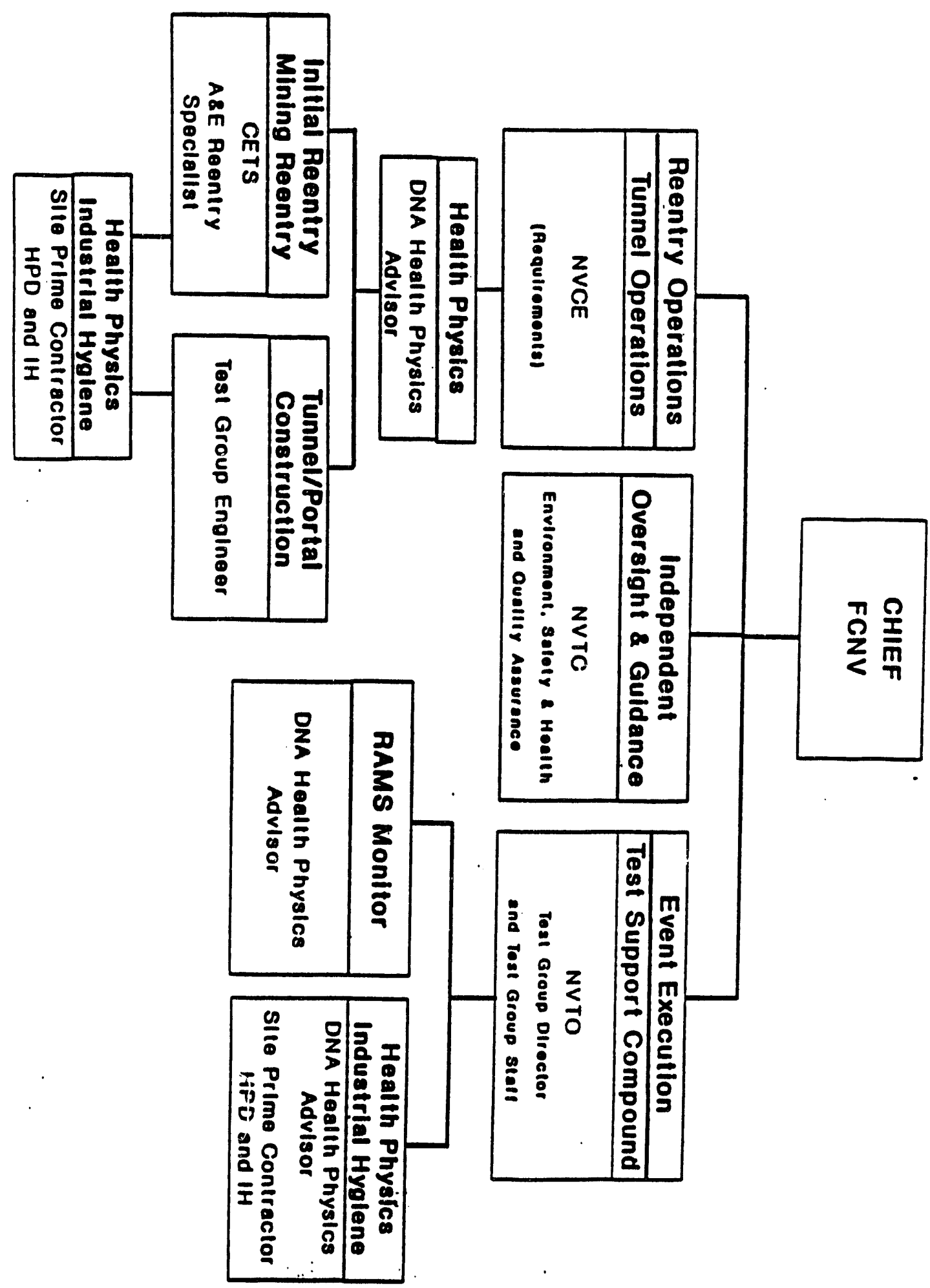




\section{DESCRIPTION OF OPERATIONS}

\section{TUNNEL ACTIVITIES}

It should be noted that although the tunnel ventilation systems are operated continuously, the release of radioactive effluent is possible only during specific operations associated with a particular test, except for the release of radon and thoron and their associated decay products. It is recognized that radon and thoron and their progeny are being continuously released from the NTS tunnels, but monitoring for these natural radioactivities in this type of facility is excluded by both the EPA NESHAP and by DOE Orders. Therefore, these emissions will not be addressed further in this document.

The tunnels currently being used for nuclear testing are $N$ and $P$ tunnels. $E, G$, and $T$ tunnels are now inactive, but are maintained in various states of readiness in case these areas are needed to support the test schedule. The ventilation systems in both $G$ and $E$ tunnels are not being operated at this time, so there is no airborne effluent from these tunnels. The $T$ tunnel ventilation system is being operated occasionally, but there is no work being conducted underground which would generate any airbome effluent other than the heretofore mentioned radon and thoron.

Similar activities are conducted in both $N$ and $P$ tunnels, so the descriptions given in this document are pertinent to both tunnels. However, since the points of discharge are different, the distance to the maximally exposed individual offsite might vary slightly.

The ventilation systems in all NTS tunnels are operated in the exhaust mode. This means that fresh air is drawn in through the portal or adit of the tunnel, sweeps through the tunnel complex, and is exhausted through the ventilation lines from the active regions of the tunnel. Thus, any radioactive effluent released any place in the tunnel complex is drawn toward the end of the ventilation line, where it is picked up and removed from the tunnel. Therefore, samples of the air taken before the air stream enters the ventilation line represent the maximum concentration of radioactivity which can be discharged through that ventilation system.

\section{PREPARATION OF THE TEST BED}

The fielding of a typical tunnel event is initiated with the mining of the test bed according to the engineered design for that particular test. An experiment drift and parallel bypass drift are mined off of the main tunnel. Instrumentation alcoves and associated access drifts are also mined. Figure C.2 contains a diagram of a typical tunnel complex. A tapered line-of-sight (LOS) pipe is installed in the experiment drift which provides a path for the prompt radiation from the source device to various experiments located internal to the pipe. The experiments to be exposed are installed in the LOS pipe by personnel from the various agencies associated with the test, and cables are emplaced from the experiments to the data recording instrumentation located in the instrumentation alcoves. The region of the LOS drift between the pipe and tunnel wall, as well as the bypass drift for some fixed distance, is filled with various grout mixtures to meet the containment criteria for the test. A simplified diagram of an LOS pipe is shown in Figure C.3. 


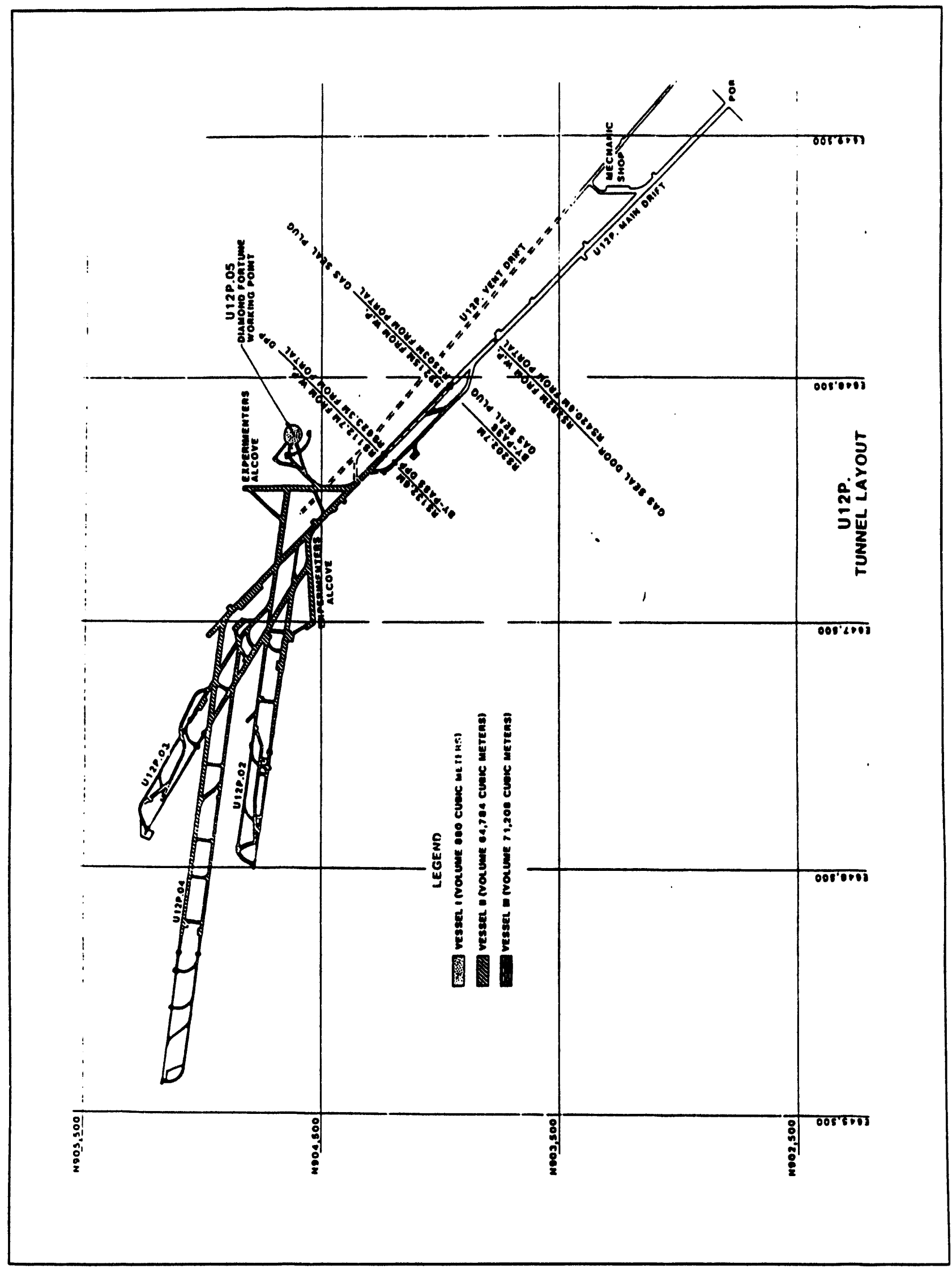

Figure C.2. Typical Tunnel Layout for Nuclear Tests (1000 ft grid) 


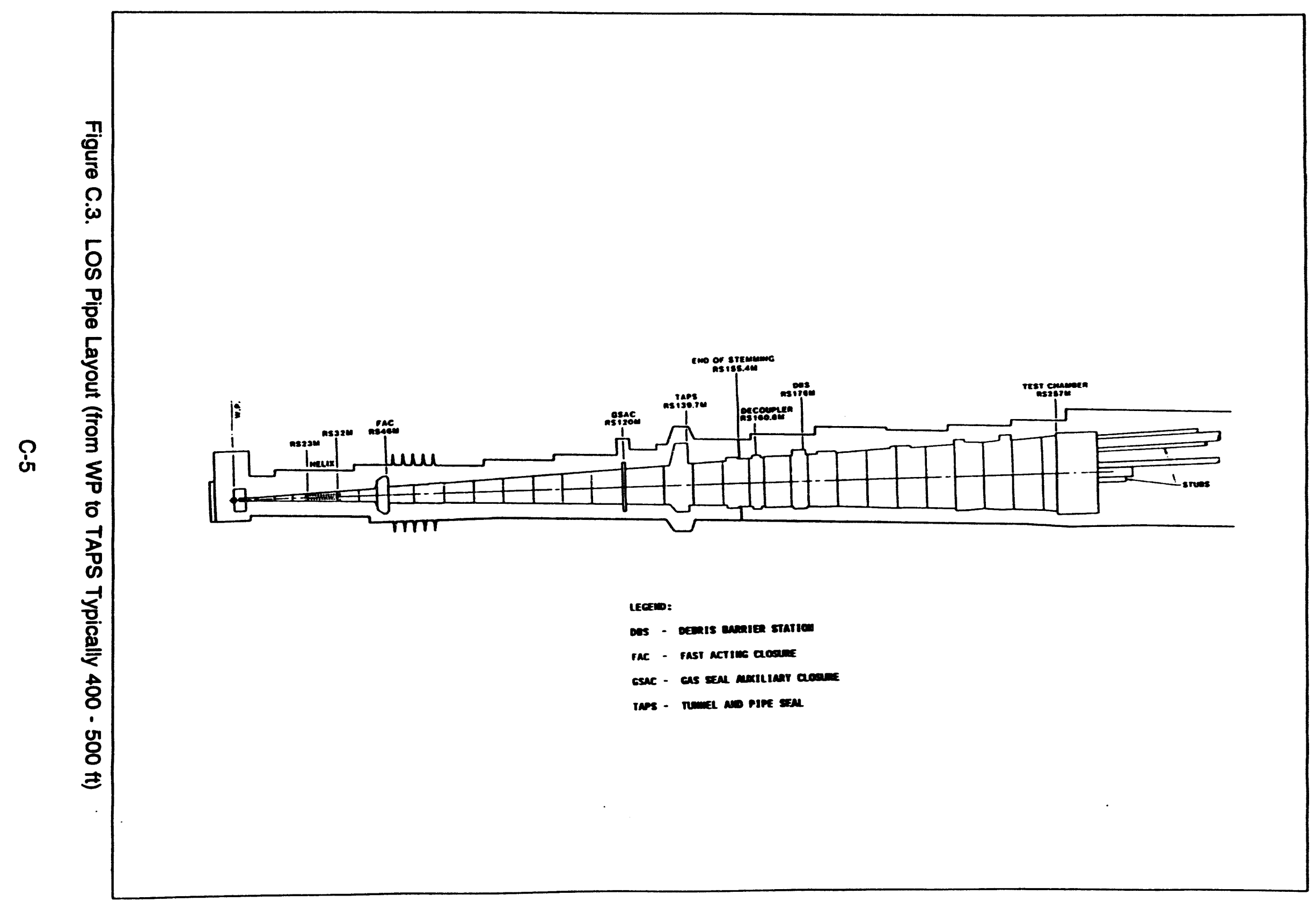


During device detonation, ionizing radiation from the source device travels down the LOS pipe to expose the experimants inside the pipe. Several mechanical closures in the pipe string seal the pipe immediately after the nuclear detonation. This design, utilizing the mechanical closures and the 8.880 ciaterd backfill materials, protects the experiments in the pipe from high velocity debris, and also provides containment of the fission products produced by the detonation of the device.

In addition to tests conducted in a horizontal line-of-sight configuration, some tests are executed in preconstructed hemispherical cavities without the use of an LOS pipe. In these tests, various detectors and experiments are placed in the walls and floor of the cavity. The source device is placed in the center of the cavity, and the access drifts are backfilled with various grout mixtures to contain the detonation products in the cavity region. Data from the test instrumentation are again recorded in the instrumentation alcoves.

During the mining and preparation of the test bed, and during experiment installation activities, no radioactive effluent is produced, 80 no radioactive effluent is released through the tunnel ventilation system.

\section{DEVICE DETONATION}

In general, an underground nuclear explosion initiates a series of events which culminate in the formation of a relatively large cavity-chimney structure in the rock. The initial cavity formation process includes the vaporization and melting of large quantities of rock and expendable experimental equipment. The containment process utilizes the energy of the device to squeeze part of the LOS pipe closed, thereby containing the detonation products in the cavity region. Much of the fission products produced is incorporated in the melted rock as it resolidifies, immobilizing this debris in the "puddle" produced at the bottom of the cavity.

Eventually the cavity gases cool and condense, which reduces pressure and allows the formation of a rubble chimney. The chimney forms by the successive collapse of overlying rock into the glass-lined cavity void. Depending on the yield, the height of the chimney may reach several hundred feet above the working point before the expansion process involved in chimney formation reaches equilibrium.

As a part of the containment design, several large concrete and steel plugs are constructed at strategic points within the tunnel complex. These plugs form a system of nested vessels which incorporate increasingly larger volumes of the tunnel. If containment of the detonation products within the cavity region is not completely successful, any radioactive debris which might be released into the experiment area of the test bed will be contained within one of these vessels. Since the ventilation system is shut down and sealed off at this time, there is no release to the environment. All releases associated with tunnel tests since 1971 have initially been completely contained within the tunnel complex, and releases have only occurred during controlled purging of the tunnel complex in order to restore the complex to normal operation.

The potential exists for a release to occur from the point of detonation to the surface by seepage through the overlying rock. However, tunnel tests are considerably overburied for the yields involved. No tunnel test conducted in the tuffaceous rocks of the Rainier Mesa test locations has released radioactivity to the atmosphere via this mechanism. 
Although the potential exists for radioactive gases to be released into the working areas of the tunnel, this debris is expected to be contained within one of the nested containment vessels, and no radioactive effluent is expected to be released to the environment. Remote area monitors (radiation detectors) located within the tunnel complex and on the surface outside the tunnel confirm containment within the tunnel and indicate the movement of flssion gases within the underground complex.

\section{INITIAL TUNNEL REENTRIES AND PURGING OF THE TUNNEL}

While the tunnel complex is being secured prior to detonation of the device, the ventilation line is disconnected at each containment plug and the penetration through the plug is sealed. Thus, it is necessary to reenter the tunnel in order to reestablish ventilation through the various containment plugs. If radioactive gases are present in a portion of the complex, it may be necessary to purge these gases from the tunnel. These gases, along with the toxic and explosive gases also produced, must be removed from the experiment areas before data and experiment recovery can begin. It is during these purging operations that the major potential exists for release of radioactive materials to the atmosphere.

\section{DATA RECOVERY}

After the initial reentries have been completed, personnel from the experimenting agencies are allowed into the instrumentation alcoves and other areas to recover film, data tapes and activation folls. As the purging operations have already removed the gaseous fission products from the complex, there are no releases of radioactive materials to the atmosphere associated with data recovery.

\section{REMOVAL OF CONTAINMENT PLUGS}

After data recovery is complete, the mining department begins removal of the containment plugs in order to reestablish the railroad track through the plugs. During this time, electrical power and lights are also being restored into the experiment area so that the experiments can be removed from the LOS pipe. During this preparation phase, all potential safety hazards (loose rock, damaged rail and/or ventilation line, etc.) are removed or repaired. There is no potential for the release of radioactive material during this phase of the operation.

\section{EXPERIMENT RECOVERIES, INSTRUMENTATION REMOVAL AND CLEAN-UP ACTIVITIES}

The experiments from inside the LOS pipe are removed to allow visual observation of the condition of each experiment following exposure to the radiation from the source device. These physical assessments of the experiments allow correlation to be made between the condition of the experiment and the active measurements made on the experiment at the time of the exposure. These observations make interpretation of the data easier and more meaningful.

During experiment recovery, some radioactive dust may become airborne and entrained in the exhaust air removed from the tunnel. This dust is the result of the deposition of the radiation energy in the experiment components and the resultant spall of the exposed surfaces (a phenomenon referred to as blowoff). This dust may be radioactive as the result of neutron activation of the materials exposed, and may also contain some particulate fission products if the device debris was not completely contained. Releases during this phase of tunnel 
operations are composed of airborne dust which contains activation products and, occasionally, particulate daughters of the noble gases which were not contained. Removal of instrumentation from alcoves and cleanup of the test bed region generally do not generate any radioactive effluent.

\section{GAS SAMPLING OPERATIONS}

Gas samples are occasionally taken from the chimney region after a nuclear test to provide information useful in understanding containment phenomenology. Prior to the test, containers of tracer gases may be located in various stemming regions and in drill holes in the insitu rock around ground zero. Some time after device detonation (usually 30 days or more) a hole is drilled into the chimney region through which samples of the cavity gases can be withdrawn. These gases are analyzed in the laboratory, and the data are used to provide a better understanding of cavity formation and growth, and thus increase our knowledge about containment mechanics.

During gas sampling operations, some excess gas is produced for which disposal is required. This gas is passed through a HEPAcharcoal filter combination, and then discharged into the tunnel ventilation system. Releases associated with gas sampling operations may occur both during the drilling of the sampling hole and during the actual gas sampling operations.

\section{REENTRY MINING}

Reentry mining is effected on many events to assess the performance of the mechanical closures and to determine the size and shape of the chimney formed by the nuclear detonation. This is accomplished by mining a reentry drift, typically from the end of stemming in the bypass drift and parallel to the LOS drift. At points of interest, crosscuts are mined from the reentry heading to the LOS drift to expose the LOS pipe and the various closures. If the rock and associated grouting materials near the LOS pipe have become contaminated, some radioactive dust may become airbome and be removed from the work area by the ventilation system.

\section{ASSESSMENT OF MECHANICAL CLOSURE PERFORMANCE}

One of the goals of postshot activities and reentry mining is to assess the performance of the mechanical closures which close-off the LOS pipe. Gases (toxic, explosive, and sometimes radioactive) may be trapped in the LOS pipe between these various closures. In order to enter the LOS pipe to observe the closures, it is necessary to remove the gases from the regions of interest. After sampling and analysis of the gases so contained, this material is purged from the LOS pipe and discharged into the tunnel ventilation system.

\section{ATMOSPHERIC PUMPING}

The only time this phenomenon is observed in the tunnels is when reentry mining has progressed to a point near the chimney region (within 50-70 feet) and probe holes are drilled into the chimney to define chimney size and shape. Current practice is to grout these holes as soon as possible after the radiation and temperature logs have been completed. If barometric pressure drops while the hole is open, the hole may breathe, releasing noble gases into the tunnel where the radioactivity is picked up by the ventilation system. This is a very insignificant source of release to the atmosphere from a tunnel test. 


\section{TEST SUPPORT COMPOUND}

The Test Support Compound (TSC) is a facility within Area 12 Base Camp used by DNAsponsored experimenters/contractors to prepare experiments before fielding, and to disassemble experiments after post-event recovery. Due to the proprietary or classified nature of some experiments, this facility is a fenced area that may have (depending on operations) round-the-clock security personnel controlling access.

Experiments are usually placed in cassettes, which are often metal boxes designed to hold shielding material to protect the experiment during the event. The cassettes are then installed in the LOS Pipe for exposure. Following the event the cassettes are taken back to the TSC where experimenters disassemble the cassettes to retrieve their experiments. Disassembly usually takes place on downdraft tables fitted with high-efficiency particulate aerosol (HEPA) filters to capture particulates.

During disassembly, some radioactive dust may become airborne and entrained in the downdraft table exhaust. This dust is the result of the deposition of the radiation energy in the experiment components and the resultant spall of the exposed surfaces (a phenomenon referred to as blowoff). This dust may be radioactive as the result of neutron activation of the materials exposed, and may also contain some particulate fission products if the device debris was not completely contained. Releases during disassembly at the TSC are composed of aiborne dust which contains activation products and, occasionally, particulate daughters of the noble gases which were not contained. In the past, only radon and thoron daughters were seen.

\section{TUNNEL PONDS}

Tunnel ponds are located at the portals of $E, N$, and T-tunnels. $E$ and $T$ tunnels are inactive but their ponds still receive water produced by gravity drainage of the tunnel complexes. Perched water in rock fractures exposed within the tunnel complex is the common source. $N$ tunnel is still active and its ponds receive natural fracture water and excess water used in construction operations (e.g., drilling).

As a result of an underground nuclear detonation, any water in the vicinity of the nuclear cavity may become radioactively contaminated. Reentry mining near the cavity may allow this contaminated water to seep into the reentry dritts; it is then is drained from the tunnel into the ponds. The ponds are unlined 80 the water may seep into the subsurface as well as evaporate. The water may contain many radionuclides, but only tritium (as HTO) will evaporate.

\section{RADIONUCLIDES WHICH COULD BE RELEASED DURING EACH PHASE OF THE OPERATION}

\section{TUNNEL ACTIVITIES}

The various phases of preparation, device detonation, and post-event operations involve different probabilities of emission of radioactivity as iollows:

- Preparation of the Test Bed - No releases excep! naturally occurring gases

- Device Detonation - No probable releases 
- Initial Tunnel Reentries and Purging of the Tunnel - If a release into the tunnel complex occurs, purging of the tunnel may release noble gases $\left({ }^{85,86 m, 80} \mathrm{Kr}\right.$ and $\left.{ }^{131 \mathrm{~m}, 133,133 \mathrm{~m}, 138} \mathrm{Xe}\right)$ and perhaps small quantities of lodine-133 and iodine-131. Typical release scenarios may involve diffusion through the rock and/or stemming materials, which removes most iodines which may be present. A release during this phase of the operation is typically of the order of 100 curies or less of noble gases, with microcurie to millicurie quantities of the radioiodines (although the highest during the past twenty years was 36,000 curies of noble gases associated with purging of tunnel complex following the MIGHTY OAK event).

- Data Recovery - No probable releases

- Removal of Containment Plugs - No probable releases

- Experiment Recoveries, Instrumentation Removal and Cleanup Activities - Experiment recoveries may generate small quantities of radioactive dust which might contain activation products, and there may also be volatile fission products and some particulate fission products which are the daughters of the noble gases. Releases during this phase of the operation are typically in the millicurie and less range.

- Gas Sampling Operations - Typically a few curies of noble gases may be released during sampling operations. Some possibility exists for the release of microcurie amounts of radioiodines and rutheniums.

- Reentry Mining - Reentry mining produces dust which is removed from the reentry heading by the tunnel ventilation system. This dust may contain activation products produced by neutron activation of the LOS pipe and some particulate fission products. These releases are in the millicurie range.

- Assessment of Mechanical Closure Performance - Releases associated with purging the LOS pipe between the various LOS closure systems usually contain noble gases (0.5 to 1.0 curie), and may also include microcurie quantities of ${ }^{131} /$ and the particulate, ${ }^{137}$ Cs.

- Atmospheric Pumping - Reentry mining to the region of the cavity usually takes several months. Only long-lived noble gases are released by this mechanism; the other noble gases have usually decayed to insignificant amounts.

\section{TEST SUPPORT COMPOUND}

Experiment disassembly on downdraft tables may generate small quantities of radioactive dust which might contain the activation products ${ }^{24} \mathrm{Na},{ }^{54} \mathrm{Mn},{ }^{60} \mathrm{Co},{ }^{124} \mathrm{Sb}$ and ${ }^{182} \mathrm{Ta}$. In addition, some particulate fission products, which are the daughters of the noble gases, may be released $\left({ }^{89} \mathrm{Sr},{ }^{80} \mathrm{Sr},{ }^{137} \mathrm{Cs}\right.$ and $\left.{ }^{140} \mathrm{Ba} / \mathrm{L}\right)$. Releases during the disassembly operation are typically in the millicurie and less range.

\section{TUNNEL PONDS}

The ponds receive several radioisotopes in the discharge water that include ${ }^{230} \mathrm{Pu},{ }^{230} \mathrm{Pu},{ }^{3} \mathrm{H}$, ${ }^{137} \mathrm{Cs},{ }^{123} \mathrm{Sb}$, and ${ }^{106} \mathrm{Ru}$. During evaporation of the pond water, tritium vapor $\left({ }^{3} \mathrm{H}\right)$ is the most likely to be released to the atmosphere. 
PROCEDURES USED FOR ESTIMATING QUANTITIES OF RADIONUCLIDES RELEASED

\section{RATIONALE}

The following procedures used for estimating the quantities of radionuclides released are based on the historical level of releases, established performance of current and experimental measurement systems, and cost benefit considerations.

The highest potential for a release from normal tunnel operations may occur during the purging of noble gases from the tunnel complex following an event. In 1985, an array of portable noble gas samplers was placed on the mesa, in addition to the existing air sampling network at the site. Following tunnel purging operations, analysis of gas samples from this experimental array showed no significant difference in the amount of noble gases detected by the array versus current procedures for estimating quantities of radionuclides released.

TUNNEL ACTIVITIES

\section{GENERAL}

When the Remote Area Monitoring system is on line, typically for five to ten days following device detonation, radiation readings from these detectors may be used to provide either an estimate of activity within the tunnel, or an estimate of activity released through the ventilation system, or an estimate of the activity released directly to the environment in the unlikely event that this should occur. The reading of the radiation detector is utilized along with the volume of the tunnel affected, or the ventilation flow rate, or the wind speed and standard atmospheric diffusion parameters, respectively, to provide an estimate of the radioactivity involved using standard calculational models. The models used are described in the document SC-RR-68559, "The Determination of the Quantity of Radioactivity Contained in a Gaseous Effluent at the Nevada Test Site Using Gamma Dose-Rate Measurements." The error associated with using these radiation detectors for release calculations ranges from a factor of two to about a factor of ten. The larger errors are associated with a release directly to the environment, a situation which is rarely experienced using current containment designs.

\section{PURGING OF THE TUNNEL}

Noble gases which seep into the tunnel complex after detonation of the nuclear device are contained within a specific volume of the tunnel as defined by the various containment plugs. Volumes of these different regions of the complex are fairly accurately known from the as-built drawings for the facility. The specific volume of tunnel affected by a particular release is defined by indications of the presence of radiation by the remote area monitors fielded for the test. Samples of the gas are taken from the tunnel using the remote gas sampling system. These samples are analyzed in the laboratory, providing the concentration of gases in the tunnel. Knowing the volume containing the radioactive gases, and the concentration of same, one can calculate the activity present in the tunnel available to be released through the ventilation system [Activity $(\mathrm{Ci})=$ Volume $(\mathrm{mL}) \times$ Concentration $(\mathrm{Ci} / \mathrm{mL})$ ]. The ventilation system is equipped with HEPA and charcoal filters when purging radioactive gases.

The largest error associated with this procedure is the assumption that the gases are uniformly mixed within the volume of tunnel affected. Typical sampling locations are selected such that the noble gas concentration in the samples obtained are usually high with respect to the average concentration. Data from the remote area monitors indicate that uniform mixing has not occurred, and past experience has shown that this technique overestimates the radioactivity released, usually by a factor of approximately two. 


\section{EXPERIMENT RECOVERIES}

During experiment recovery operations, air samples are taken from inside the LOS pipe and from the experiment bagging area outside the pipe. These samples are taken using Whatman 41 filter paper backed up with a 1" charcoal filter. A vacuum pump is used to pull the sample through the filter assembly, and a low pressure gas meter is used to measure the total amount of air sampled. The samples are analyzed in the laboratory, and the concentration of radionuclides detected is reported.

Since the tunnel makeup air sweeps the recovery area before exiting the tunnel through the ventilation system, these air samples would represent the maximum concentration levels which could be released at the point of discharge. Additionally, the ventilation air from the recovery area is diluted by air from other branches of the ventilation system before release, further lowering the concentration at the point of discharge. Air samples taken from the ventilation line near the point of release seldom indicate the presence of any activation or fission products during recovery operations. Although these vent line samples are not taken isokinetically, they do at least confirm that the emission sources are indeed small.

Although the vent line samples are not currently used to project effluent releases during recovery operations, these samples could provide estimates that are accurate to within approximately a factor of two. Release estimates made using air samples taken in the recovery area would probably overestimate a potential release by at least a factor of ten. Either technique would assure that effluent releases during recovery operations are well within NESHAP guidelines. Isokinetic sampling is being tested to provide confirmation of these estimates.

\section{GAS SAMPLING OPERATIONS}

During gas sampling operations, gas from the cavity region is pumped through a calibrated mass flow meter before being discharged into the tunnel ventilation systern. A representative sample of the gas is taken and analyzed in the laboratory. The concentration of radionuclides thus determined multiplied by the total volume of gas discharged gives an estimate of the radioactivity released. This estimate is accurate to within ten percent since the only errors are in the measurement of the volume of gas pumped into the ventilation line and the errors associated with sample analysis.

\section{REENTRY MINING}

Air samples are taken continuously in the reentry heading using the techniques described in the above section on Experiment Recoveries. These samples are taken as close to the end of the vent line as is possible, and are analyzed in the laboratory. Samples are also taken from the ventilation line at the point of discharge. Again, these vent line samples are not taken under isokinetic conditions, but do confirm that any releases during mineback activities are small. Drierite sample are taken in the reentry heading near the end of the ventilation line at least weekly to determire if any tritium is present as water vapor. These samples are analyzed in the laboratory, and indicate that tritium releases associated with reentry mineback operations are also quite small.

As soon as the reentry operation is complete, current practice is to construct a plug in the reentry drift. No further releases from the reentry operation can occur once the plug has been completed. 


\section{ASSESSMENT OF MECHANICAL CLOSURE PERFORMANCE}

During these operations, a sample of the gas inside the LOS pipe between various closure systems is taken and is analyzed in the laboratory. The volume of the LOS pipe between closures is accurately known, so the activity of the gas available to be released can be easily and accurately determined [Activity $(\mathrm{Ci})=$ Volume $(\mathrm{mL}) \times$ Concentration $(\mathrm{Ci} / \mathrm{mL})$ ]. The error in this estimate should be less than ten percent.

\section{ATMOSPHERIC PUMPING}

If a release occurs from a tunnel as a result of falling barometric pressure, a sample of the gas is taken from the drill hole in a vacutainer and sent to the laboratory for analysis. An estimate of the flow rate from the hole is made (or the flow rate is measured if the proper instrumentation is available), and the volume of gas discharged is calculated from the flow rate and the length of time the release occurred. This volume multiplied by the concentration of the sample taken gives the activity discharged.

The error of the estimate in this situation is primarily determined by how well the flow rate from the drill hole is known. Since the estimate of the flow rate could be in error by a factor of ten, the calculated effluent release as the result of atmospheric pumping is no better than a factor of ten. However, the concentration of gases in the chimney region during the time that this phenomenon might be observed is quite low so releases associated with atmospheric pumping in the tunnels are also quite low.

\section{TEST SUPPORT COMPOUND}

During experiment disassembly operations, air samples are taken from the down draft table vent stacks and at several locations in each building. These samples are taken using Whatman 41 filter paper backed up with a 1" charcoal filter. A vacuum pump is used to pull the sample through the filter assembly, and a gas lpg meter is used to measure the total amount of air sampled. The samples are analyzed in the laboratory, and the concentration of radionuclides detected is reported.

Since the air sweeps down onto the table and over the disassembled experiments before exiting through the vent stack, these air samples would represent the maximum concentration levels which could be released at the point of discharge. Air samples taken from the ventilation stack near the point of release seldom indicate the presence of any activation or fission products during experiment disassembly operations. Although these vent stack samples are not taken isokinetically, they do at least confirm that the emission sources are indeed small.

Although the vent stack samples are not currently used to project effluent releases during experiment disassembly operations, these samples could provide estimates that are accurate to within approximately a factor of two. Release estimates made using air samples taken in the disassembly area and table ventstack would piubably cverestimate a potential release by at least a factor of ten. Either technique would assure that effluent releases during disassembly operations are well within NESHAP guidelines.

\section{TUNNEL PONDS}

Grab samples of discharge water and water in the ponds are taken monthly. These samples are analyzed for tritium and gross beta, and by gamma spectrometry. Every quarter the samples are analyzed for plutonium, and once each year the samples are analyzed for 
strontium. Tritium releases, in the form of water vapor, are estimated by assuming the entire tunnel water discharge evaporates. Currently, this is a very conservative method and probably overestimates the releases by about 50 percent. However, plans call for eliminating all discharges during 1994.

As of May 1991, a water characterization/monitoring system was installed at each of the three water-producing tunnels. This system continuously monitors the physical properties of the water (flowrate, pH, etc.). Periodically a sample is collected for chemical and radiological water quality analyses. These samples are used to calculate an air effluent by assuming total evaporation.

\section{SUMMARY}

There are a number of operations associated with weapons effects tests conducted in NTS tunnels which have the possibility of releasing some airbome radioactive effluent. This document has attempted to describe the various operations associated with a tunnel test, the radionuclides which might be released, and the procedures currently used to verify that the releases are indeed small. It is believed that all potential airbome release pathways have been identified, and that the dose to the maximally exposed individual in the offsite area is well below 0.1 mrem/year. As these small releases lead to exposures well below the guidelines for exposures to offsite people, only periodic confirmatory measurements are required to demonstrate continuing compliance with NESHAP. It is the DNA's contention that monitoring at the source of production of the potential effluent provides such confirmation.

\section{REPORTS RELATED TO EFFLUENT MEASUREMENTS AND MONITORING}

- SC-RR-68-559; "The Determination of the Quantity of Radioactivity Contained in a Gaseous Effluent at the Nevada Test Site Using Gamma Dose Rate Measurements," P. O. Matthews, December, 1968

- Event Effluent Documentation Reports - Distribution: Bernard F. Eubank, REECo; P. K. Fitzsimmons, DOE/NV; J. W. LaComb, DNA; D. A. Bedsun, DNA; F. D. Ferate, REECo; SNL Division 7713 Files

- Water Pollution Control Permit Applications \& Periodic Monitoring Reports for Waste Water Discharges from E, N, \& T Tunnels - Distribution: J.W. LaComb, DNA; Paul Liebendorfer, Nevada Department Environmental Protection; D.R. Elle, DOENNV; W.G. Flangas, REECo 


\section{APPENDIX D}

\section{BUILDING 650 HEALTH PHYSICS LABORATORY}

RADIONUCLIDE INVENTORY 


\section{INTRODUCTION}

The following approach was used to calculate the inventory of radionuclides in the Health Physics (HP) Laboratory located in Building 650, Mercury, Nevada Test Site.

- The number of samples processed during a week was totaled and documented.

- The total activity for each radionuclide analyzed was calculated for all samples in liquid form (or in liquid form during any stage of radiochemistry). Gamma activity inventory from solid samples (soil, filters not solubilized, charcoal cartridges, etc) was orders of magnitude below liquid samples, and was therefore not included.

- When the number of samples of any type processed during the week was less than typical (in the health physicist's judgement), the number of samples was modified accordingly. In each case, the modification increased, never decreased, the documented number of samples.

- The calculated activity in the Laboratory is documented in the NTS Environmental Monitoring Plan.

- The sample throughput capability of the Laboratory cannot increase much more than two times its actual capacity. Therefore, an error of 200 percent may be applied.

- The radionuclides contained in standards, check sources, and tracer solutions were also inventoried. The activity contained in these sources was orders of magnitude above that contained in samples so they are listed in Table D.1 below where they are compared to possession limits.

From the inventory, only one of the items may become a source of air emissions. This is ${ }^{3} \mathrm{H}$ (as HTO) and is listed in Table 2, above. The remainder of the standards are compared to the possession limits set forth in 40CFR61, Appendix E, and all are less than 0.1 percent of those limits.

Table D.1. Building 650 Health Physics Laboratory Inventory Compared to NESHAP

$\underline{\text { Radionuclide }}$

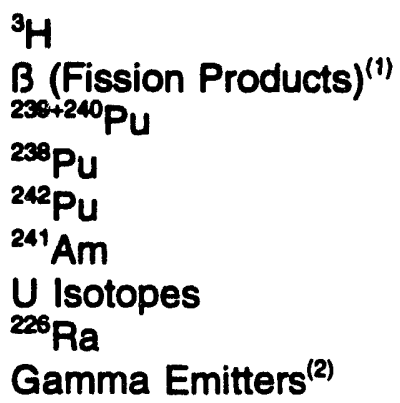

Annual Inventory (CiYear)

$6.4 \times 10^{-6}$

$2.9 \times 10^{-6}$

$9.7 \times 10^{-10}$

$5.5 \times 10^{-10}$

$2.5 \times 10^{-0}$

$1.0 \times 10^{-6}$

$8.7 \times 10^{-9}$

$3.1 \times 10^{-7}$

$1.4 \times 10^{-5}$
NESHAP Possession Quant. (Ci/vear Liquid Form)

$1.5 \times 10^{4}$

$5.2 \times 10^{-1}$

$2.5 \times 10^{-3}$

$2.7 \times 10^{-3}$

$2.5 \times 10^{-3}$

$2.3 \times 10^{-3}$

$8.6 \times 10^{-3}$

$5.5 \times 10^{-3}$

(1) Beta (fission products) plus ${ }^{14} \mathrm{C},{ }^{89} \mathrm{Sr},{ }^{129} \mathrm{I}$, and ${ }^{90} \mathrm{Tc}$ are compared to the ${ }^{80} \mathrm{Sr}$ annual possession quantity (40CFR61 Appendix E, Table 1).

(2) Gamma emitters is the sum of all such isotopes in the Laboratory not listed separately above. The isotope with the largest dose conversion factor is ${ }^{109} \mathrm{Cd}$ so the possession quantity for that radionuclide is used. The gamma emitters included ${ }^{57} \mathrm{Co},{ }^{60} \mathrm{Co},{ }^{88} \mathrm{Y},{ }^{89} \mathrm{Sr}$, ${ }^{169} \mathrm{Cd},{ }^{13} \mathrm{Sn},{ }^{137} \mathrm{Cs},{ }^{139} \mathrm{Ce}$, and ${ }^{203} \mathrm{Hg}$. 
APPENDIX E

CONTAINMENT PONDS 


\section{EMISSION FROM THE TUNNELS AND PONDS}

Water in the containment ponds located at the Area 12 tunnel complexes was sampled once each month. These water samples are analyzed for radionuclides by gamma spectroscopy, for gross beta, and for tritium. Less frequently, other samples are collected for analysis of plutonium and strontium. The total amount of radioactive liquid effluent from the tunnels is calculated from the concentration of radionuclides in the water and the total volume of water discharged in the year. T'ie volume of water discharged from the tunnels was measured by use of a weir.

In order to calculate doses using CAP88-PC an airborne source term must be known. As described above, the total liquid effluent volume is measured and the radionuclide concentrations are determined from analysis of monthly samples. By assuming that the total amount of tritium measured in the liquid effluent during the year evaporates and becomes airborne, an airbome source term is obtained. It is unlikely that this is an accurate representation of the actual process at the containment ponds but it is an upper limit of the effluents which could be released. The fact that the concentration of tritium in the ponds at the beginning and end of the year has been relatively constant' lends credence to this calculation. The tunnels are in the process of being sealed so the effluents are decreasing with time.

Table E.1 below, lists the total quantity of tritium discharged into the containment ponds (and assumed to be released as airborne effluents) as measured during CY-1993.

Table E.1. Tritium Effluents into Containment Ponds

Location

Area 12, T Tunnel

Area 12, N Tunnel

Area 12, E Tunnel
$\operatorname{Area}\left(\mathrm{m}^{2}\right)$

930

1120

250
Total ${ }^{3} H$ Discharged (Ci)

644.2

0.33

59.7

Total Effluent

704

Airborne HTO emissions were measured for 127 days at the $P$ Tunnel portal. Assuming similar emission rates for the whole year, $3.7 \mathrm{Ci}$ of $\mathrm{HTO}$ were emitted. When added to the above, the total HTO emission used in calculating EDE was $708 \mathrm{Ci}$.

1 - For example: Tunnel Pond \& No. Result $\left(\bar{X}_{ \pm}^{-}\right) \quad$ Mo.Mr.

N No. 2

T No. 2
$8.5 \pm 1.3 \times 10^{-5}$

$2.8 \pm 1.9 \times 10^{-4}$

$4.9 \pm 0.5 \times 10^{-2}$

$5.6 \pm 0.4 \times 10^{-2}$
$02 / 92$

$12 / 92$

02/92

$12 / 92$ 
APPENDIX F RESUSPENDED PLUTONIUM FROM YUCCA FLAT 


\section{BACKQROUND INFORMATION}

As previously described, Area 3 is a diffuse source of radionuclide effluents. Due to operational activities, such as vehicular traffic, equipment operation, etc., some plutonium becomes airborne. Resui. ; from the air samplers in the area indicate that only ${ }^{230+240} \mathrm{Pu}$ is routinely detected and only in concentrations slightly above the MDC.

Measurements of airborne ${ }^{230+240} \mathrm{Pu}$ in Area 3, during CY-1993, are provided in Table F.1. This table displays the number of samples analyzed, the median value and the standard deviation of the 11 or 12 values. Because Area 3 is an area source, it is difficult to measure the volume of air discharged. Therefore, the source term must be estimated. In order to obtain a source term in Cilyr from the area, the measured ${ }^{230+240} \mathrm{Pu}$ concentration was used in conjunction with CAP88-PC in order to back-calculate a source term. For convenience, the source was assumed to be an area in the center of a circle that touches the four sampling locations (worst case assumption).

Table F.1. Airborne ${ }^{239+240} \mathrm{Pu}$ Detected by the Area 3 Air Samplers

$\begin{array}{lccc}\text { Lecation } & \begin{array}{c}\text { Number of } \\ \text { Samples }\end{array} & \text { Median } & \begin{array}{c}\text { 1 Standard } \\ \text { Deviation }\end{array} \\ \text { Area } 03 \text { Complex } & 12 & 48 & 160 \\ \text { Area } 03 \text { Complex No. } 2 & 12 & 40 & 230 \\ \text { Area } 03 \text { Mud Plant } & 11 & 119 & 160 \\ \text { Area 03 U3ahat (4 Samplers) } & 11 & 59 & 120\end{array}$

\section{SOURCE TERM}

It is estimated that $1 \mathrm{mCi}(37 \mathrm{MBq})$ of ${ }^{230+240} \mathrm{Pu}$ may have been emitted from Area 3. This source term is only probable because it is a worst case value that is based on calculations and an assumed location rather than on monitored values. The method used to calculate this quantity is described below.

The CY-1993 median concentration of ${ }^{230+240} \mathrm{Pu}$ at the Area 3 samplers was tabulated as above. Using the dose conversion factor of $460 \mathrm{rem} / \mu \mathrm{Ci}$ derived from ICRP EDE limits and $8400 \mathrm{~m}^{3}$ annual average air intake per person, an EDE can be calculated for a person remaining all year at that sampler location.

A trial run of CAP88-PC using a $1 \mathrm{Ci}$ release from the center of the samplers gives an EDE at each of them. When the calculated EDE at each sampler is divided by the EDE/Ci from the CAP88-PC run, then an estimate of the curies released can be obtained.

The following shows a typical calculation,using 1st sample in Table F.1:

\section{$4.8 \times 10^{-6} \mathrm{pCT} \mathrm{m}^{3} \times 8400 \mathrm{~m}^{3} / \mathrm{gr} \times 0.46 \mathrm{mrem} / \mathrm{pCg}=0.18 \mathrm{mrem}$}


A CAP88 run using $1 \mathrm{Ci}$ and $670 \mathrm{~m}$ distance indicates an EDE of $520 \mathrm{mrem}$ at the location of the sampler. The ratio of 0.18 to 520 gives $3.5 \times 10^{-4} \mathrm{Cl}$ or an emission of $0.35 \mathrm{mCl}$. Using the data in the above table indicates the maximum emission (based on the Mud Plant sampler) would be $2 \mathrm{mCl}(74 \mathrm{MBq})$. This can reasonably be adjusted to $1 \mathrm{mCl}(37 \mathrm{MBq})$. The boundaries of the plutonium contaminated areas have only extended a few meters since the 18608 , and of the amount resuspended only a fraction would be in particle sizes small enough to be carried very far by the wind.

Using $1.0 \mathrm{mCl}(37 \mathrm{MBq})$ as a conservative source term for the radionuclide as input to CAPB8-PC yields an EDE of $5.5 \times 10^{-4} \mathrm{mrem}(5.5 \mathrm{nSv})$ to a person in Lathrop Wells, Nevada, $54 \mathrm{~km}$ to the southwest. This is the MEI for a source in Area 3 of the NTS.

\section{ERAOR TERM}

The errors in the measurements are listed in Table F.1 as a standard deviation so the EDE is actually between 0 and $5.5 \times 10^{-4} \mathrm{mrem}(0$ and $5.5 \mathrm{nSv}$ ). However, the errors in the method employed in arriving at a source term, as described above, are very difficult to assess.

\section{CALCULATION OF PU RESUSPENSION FROM AREA 9}

There is an air sampler in Area 9 at one end of a ground deposit of plutonium. MacArthur in DOENNV/1485-02 estimates a ${ }^{230+240} \mathrm{Pu}$ deposit of $89 \mathrm{Cl}$ in that location. If the rate of resuspension of that material can be calculated, then a source term would be available.

In the text "Radiological Assessment" by J. E. Till and H. R. Meyer, there is an equation for calculating a suspension rate (fraction resuspended per second) as follows:

$$
S=K \times V_{0}
$$

where $S=$ suspension rate $\left(\mathrm{sec}^{-1}\right)$ - fraction of the deposit resuspended/sec

$K=$ resuspension factor $\left(\mathrm{m}^{-1}\right)$

$V_{g}=$ deposition velocity $(\mathrm{m} / \mathrm{s})$

On page 5-32 of the text cited, the value of $K$ for the NTS is listed as 10.11. Deposition velocities are in the range of 0.01 to $0.1 \mathrm{~m} / \mathrm{s}$. If these values are put into the above equation, the suspension rate becomes $10^{-12}$ to $10^{-13}$ per second, and the source term becomes:

$89 \mathrm{Ci} \times 10^{-12} / \mathrm{s}=89 \mathrm{pCi} / \mathrm{s}$

1 year $=3600 \mathrm{~s} / \mathrm{hr} \times 24 \mathrm{hr} /$ day $\times 365$ days $/ \mathrm{yr}=3.15 \times 10^{7} \mathrm{~s} / \mathrm{yr}$

Annual source term $=89 \mathrm{pCi} / \mathrm{s} \times 3.15 \times 10^{7} \mathrm{~s} / \mathrm{yr}=2.8 \times 10^{\circ} \mathrm{pCi} / \mathrm{yr}$

Therefore, using both suspension rates, the emission is between 0.28 and $2.8 \mathrm{mCl} / \mathrm{yr}$ or an average of $1.5 \mathrm{mCl} / \mathrm{yr}$. This can be adjusted as described above to $0.75 \mathrm{mCi} / \mathrm{yr}$. This emission was input to the CAP88 program using the Area 9-300 bunker as the midpoint of the source. 


\section{APPENDIX G}

DIFFUSE SOURCE ATMOSPHERIC TRITIUM EMISSIONS 


\section{BACKGROUND INFORMATION}

Environmental monitoring for tritium in atmospheric moisture is conducted at 18 locations spread around the NTS. There are 9 air samplers around the Radioactive Waste Management Site perimeter in Area 5 because many curies of ${ }^{3} \mathrm{H}$ are buried at that facility. Some of these samplers collect tritium concentrations that are higher than background levels. This year, also, the monitor at the EPA Farm in Area 15 collected the next to highest tritium concentration. The monitoring results from these sampling stations are provided in Table G.1, Aliborne Tritium Sampling Results during CY-1993. The other CY-1993 monitoring data indicate that gross beta and ${ }^{230+240} \mathrm{Pu}$ concentrations are not statistically different from site-wide NTS levels.

\section{SOURCE TERM}

It is estimated that $0.29 \mathrm{Ci}(11 \mathrm{GBq})$ of ${ }^{3} \mathrm{H}$ is emitted annually from the RWMS. This source term is calculated to give an EDE of $4.9 \times 10^{-6} \mathrm{mrem}$ (49 pSv) to an individual residing in Lathrop Wells, NV. As in Appendix F, this is the location of the MEl for a source in Area 5. The method used to calculate this quantity is described below.

Once again, only environmental monitoring data were available and there was no information on the volume of air discharged from the RWMS. Considering that the RWMS processes packaged waste, it is not likely that an air volume or discharge is appropriate. However, a source term can be calculated using a method similar to that described for Yucca Flat in Appendix F.

The median annual airborne HTO concentrations from the RWMS tritium samplers surrounding the site were compared to the DOE/EH-0071 dose conversion factors to calculate a dose at each sampler location. For example, an individual breathing $15.5 \times 10^{-12} \mu \mathrm{CV} / \mathrm{mL}$ of HTO for one year receives 12.1 $\mu$ rem EDE when skin absorption is included, doses are calculated similarly for the other sampler locations. CAP88-PC calculates that an individual 305 meters to the west from a $1 \mathrm{Cl}$ release of ${ }^{3} \mathrm{H}$ at the center of the RWMS, would receive a EDE of $42 \mu \mathrm{rem}$ per year. Therefore, $12.1 \mu \mathrm{rem}$ at that sampler divided by $42 \mu \mathrm{rem} / \mathrm{Ci}$ equals an estimated annual release of $0.29 \mathrm{Cl}$. This calculation was performed for all sampler locations, as shown in Table G.1 and the $0.29 \mathrm{Cl}(11 \mathrm{GBq})$ was the maximum estimate. This calculated release was reported to the EIS/ODIS data bank.

Lathrop Wells, NV is located WSW of the RWMS at $44 \mathrm{~km}$. CAP88-PC calculates an EDE of $4.9 \times 10^{-6} \mathrm{mrem}$ to an individual residing in Lathrop Wells if 0.29 curies of HTO were released from the Area 5 RWMS.

The other sampler with elevated HTO in air median concentration is the one at the Area 15 Farm. The possible sources are the Farm, the tunnels and ponds in Area 12, and the Sedan Crater. The ${ }^{3} \mathrm{H}$ experiments at the farm used only $\mathrm{mCl}$ amounts in the early 1970 s so it is unlikely to be a source. The emissions from the other two sources (calculated as above) are shown in the table. 
It appears unlikely that $160 \mathrm{Cl}$ of HTO are being emitted from the Sedan crater. However, emissions from the P-tunnel portal, as measured with the isokinetic sampler, are estimated to have been $3.7 \mathrm{Cl}$ for 1993, and liquid effluents totaled $704 \mathrm{Cl}$ for the three tunnel ponds. Evaporation of $225 \mathrm{Cl}$ from the $708 \mathrm{Cl}$ in effluents is a reasonable guess and confirms the conservatism inherent in assuming total evaporation of all liquid effluents as was done in Appendix E. Therefore, the Area 5 RWMS and the Area 12 tunnels are considered to be the detectable sources of HTO on the NTS.

Table G.1. Airborne Tritium Sampling Results During CY-1993

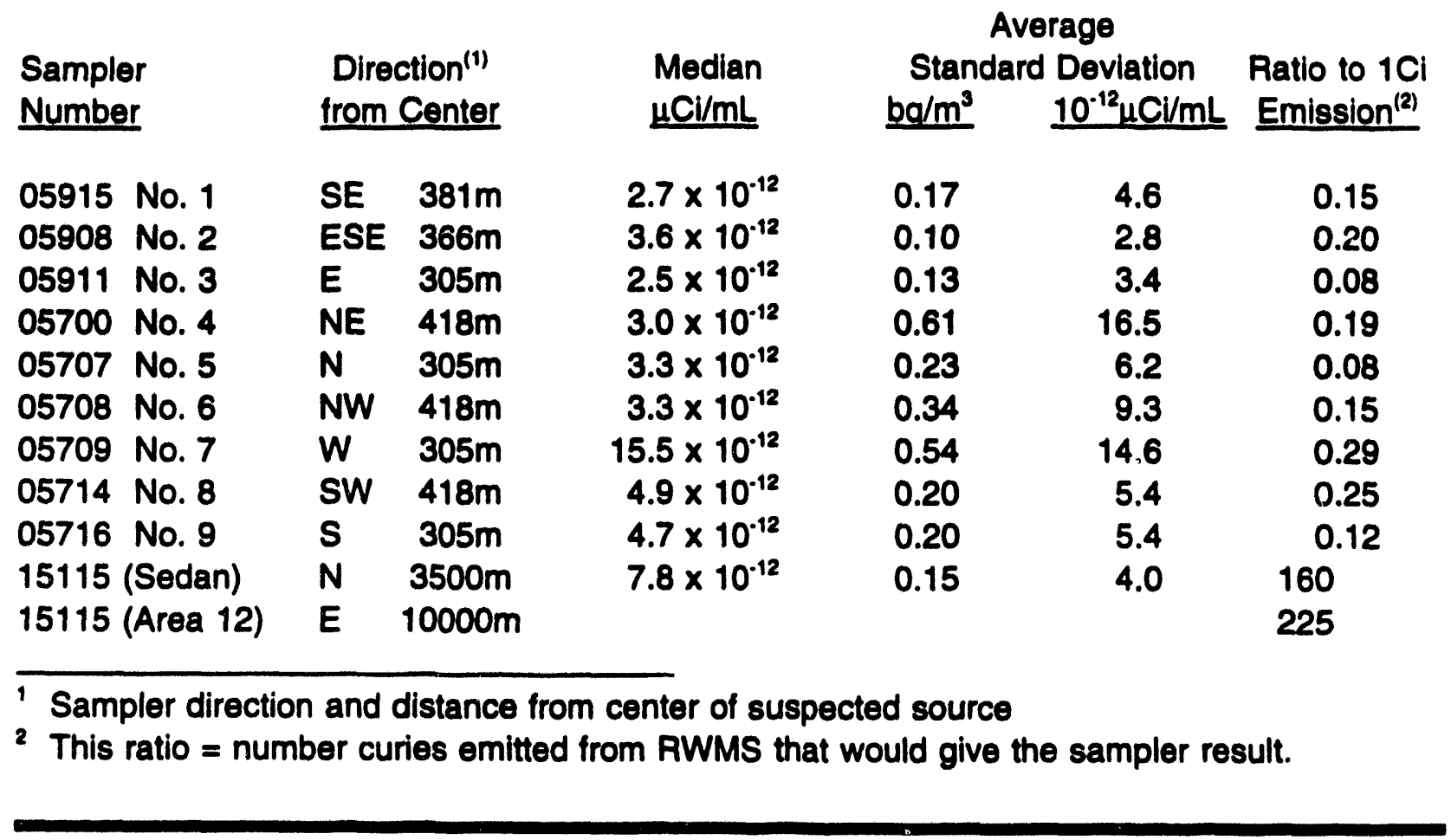




\section{APPENDIX H}

\section{SEEPAGE CALCULATION FOR PAHUTE MESA}




\section{NOBLE GAS SEEPAGE ON PAHUTE MESA}

Previous environmental surveillance and test monitoring results on Pahute Mesa have suggested that the noble gas, ${ }^{85} \mathrm{Kr}$, seeps up from nuclear test cavities to be emitted at ground surface with the result that the concentration in environmental surveillance samples is increased when compared to ambient levels measured in other locations. The process evidently requires a lengthy period of time because ${ }^{133} \mathrm{Xe}, 5.25$ days half-life, is not normally detected in these samples.

In 1992, additional permanent noble gas sampling locations were established to increase the number of monitoring stations to 10. The locations are shown in Figure H.1. At each station air is pumped into steel pressure tanks for weekly periods. The noble gases are extracted from the compressed air in these tanks using a cryogenic technique, dissolved in a scintillation cocktail and counted in a liquid scintillation counter. Because of equipment and laboratory failures, fewer than 52 results are obtained for each station. The 1993 noble-gas sampling results are shown below.

Table H.1. ${ }^{85} \mathrm{Kr}$ Concentrations on the NTS IN $1993\left(\mathrm{pCi} / \mathrm{m}^{3}\right)$

$\begin{array}{lccc}\begin{array}{l}\text { Station } \\ \text { Lecation }\end{array} & \begin{array}{c}\text { Number } \\ \text { Arithmetic } \\ \text { Average }\end{array} & \begin{array}{c}\text { Standard } \\ \text { Deviation }\end{array} \\ \text { BJY } & 39 & 26.9 & 4.4 \\ \text { Gravel Pit } & 37 & 26.8 & 6.0 \\ \text { Gate 200 } & 43 & 26.8 & 4.7 \\ \text { Area 12 Camp } & 31 & 25.7 & 5.3 \\ \text { EPA Farm } & 37 & 24.9 & 3.5 \\ \text { Area 20 Camp } & 27 & 28.4 & 5.7 \\ \text { E-MAD } & 39 & 25.6 & 4.5 \\ \text { Pahute Substation } & 25 & 27.3 & 7.8 \\ \text { Gate 400 } & 38 & 26.5 & 4.8 \\ \text { DDZ77 Trans. } & 29 & 27.4 & 5.9 \\ \end{array}$

The results from the Area 20 Camp sampler frequently have been higher than the results from the other NTS samplers. This also appears to be true for the 1993 results. The average of the 9 stations other than Area 20 was $26.4 \mathrm{pCi} / \mathrm{m}^{3}\left(0.98 \mathrm{~Bq} / \mathrm{m}^{3}\right)$ while the results for the Area 20 sampler were $28.4 \mathrm{pCi} / \mathrm{m}^{3}$, or an annual average of $2.0 \mathrm{pCi} / \mathrm{m}^{3}\left(0.07 \mathrm{~Bq} / \mathrm{m}^{3}\right)$ higher. The wind roses shown on Figure H.2 suggest that, for the Area 20 sampler, the source is to the SSE in the area between some U19 and U20 emplacement holes. This area is about $5260 \mathrm{~m}$ $(17,250 \mathrm{ft})$ from the sampler. Using a procedure similar to that in Appendices $F$ and $G$, and also using a CAP88-PC run with an assumed release of $1 \mathrm{Ci}(37 \mathrm{GBq})$ of ${ }^{85} \mathrm{Kr}$, yields a result of $160 \mathrm{Ci}(5.9 \mathrm{PBq})$ emission from ground seepage on Pahute Mesa. The calculation for this emission is shown on the following page. The dose conversion factor for ${ }^{85} \mathrm{Kr}$ is obtained from the DAC for submersion given in ICRP Report 30. The DCF is multiplied by the krypton concentration to obtain the effective dose equivalent (EDE) at the sampler location. To determine the emission necessary to cause this EDE, an assumed emission of $1 \mathrm{Ci}(37 \mathrm{GBq})$, the distance to the sampler $(5260 \mathrm{~m})$, and the STAR (stability array) meteorology for Pahute 
Mesa were entered into the CAP88-PC program. At a distance of $5260 \mathrm{~m}$ in the direction NNW, the CAP88-PC run with $1 \mathrm{Ci}(37 \mathrm{GBq})$ indicates an EDE of $2 \times 10^{-7} \mathrm{mrem} / \mathrm{yr}(2 \mathrm{pSv})$ at the sampler location. The calculations are displayed in the following three equations:

DCF for $\mathrm{KH}^{\mathrm{eb}}=1.6 \times 10^{-5} \mathrm{mrem} / \mathrm{gr}$ per $\mathrm{pCl} \mathrm{m}^{3}$

[EDE at sampled $2.0 \mathrm{pCIm}^{3} \times 1.6 \times 10^{-6}=3.2 \times 10^{-6} \mathrm{mrom} / \mathrm{yr}$

[EDE at sampler $] \frac{3.2 \times 10^{-6} \mathrm{mrom} / \mathrm{yr}}{2 \times 10^{-7} \mathrm{mrem} / \mathrm{Cl}}=160 \mathrm{Clyr}$ 


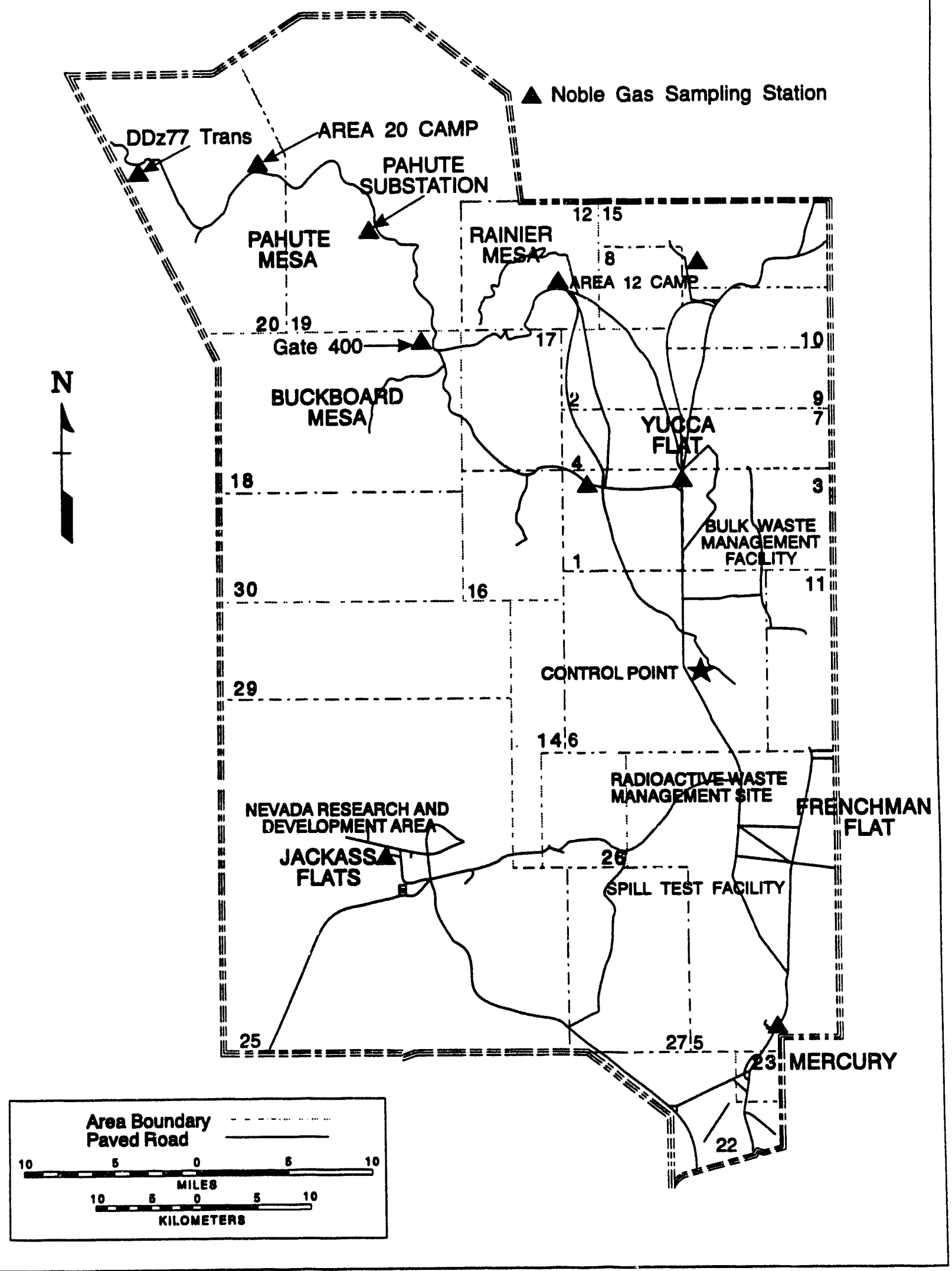

Figure H.1. Noble Gas Sampling Sites on the NTS 


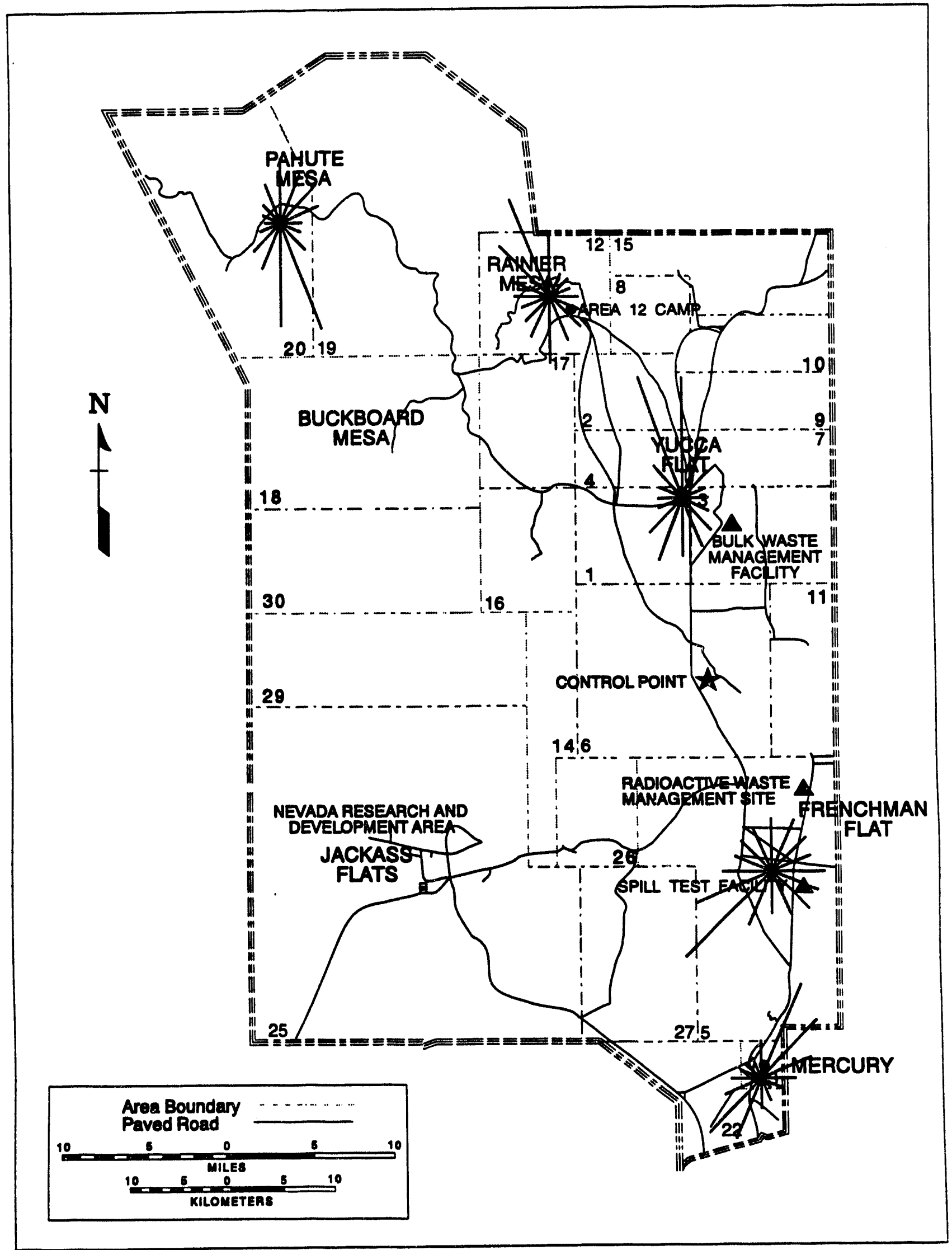

Figure H.2. Wind Roses for the Various Areas on the NTS 


\section{APPENDIX I}

IDENTIFICATION AND JUSTIFICATION FOR THE DEVELOPMENT OF METEOROLOGICAL DATA USED AS INPUT TO CAP88-PC 


\section{INTRODUCTION}

The Nevada Test Site (NTS) is located in southern Nevada, approximately $90 \mathrm{~km}(65 \mathrm{ml})$ northwest of Las Vegas, and encompasses an approximate rectangular area of $1500 \mathrm{sq} \mathrm{mi}$ (see Figure 1.1). Topography is complex with generally north-south oriented ridges and valleys typical of Nevada. Terrain elevations range from near $2700 \mathrm{ft}$. in the extreme southwest comer of the NTS (Station No. 25) to near $7700 \mathrm{ft}$ on Rainier Mesa in the northem part of the NTS (Station No. 12).

In general, terrain slopes gently into broad valleys. In the few areas where steep canyons or cliffs exist, adequate wind and temperature data have been collected and analyzed to provide thorough documentation of the existence of typical upslope and downslope wind regimes as a function of time of day.

Meteorological support, observations, and climatological services for the NTS are provided to the DOE Nevada Field Office (DOE/NV) by the Weather Service Nuclear Support Office (WSNSO). WSNSO is a National Oceanic and Atmospheric Administration (NOAA), National Weather Service (NWS) office. WSNSO supports DOE/NV programs under the authority of an Interagency Agreement between NOAANWS and DOE/NV.

An arid climate exists over the NTS. Annual precipitation ranges from 4.5 inches per year at Station No. 25 to 6.9 inches per year in Yucca Flat (Station No. 6) to 7.6 inches at Desert Rock, to 9.5 inches per year on Rainier Mesa (Station No. 12).

\section{METEOROLOGICAL OBSERVATIONS}

WSNSO manages, operates, and maintains a meteorological monitoring program that is designed and used to support DOE/NV-authorized activities on the NTS. This vital program consists of many meteorological monitoring systems that have been brought together under the acronym MIDNET, or Meteorological Data Network. This network has been operated on the NTS for over 25 years, has undergone several modernizations and upgrades, and serves as a solid basis for deriving climatological information.

MIDNET consists of communications systems, local area networks, upper-air sounding stations, and surface-based instrumentation used to measure wind direction and speed, temperature, relative humidity, and precipitation. Routine and special NWS surface observations are collected by trained NWS personnel 24 hours per day, 365 days per year at the Desert Rock Meteorological Observatory (DRA, elevation $3304 \mathrm{ft}$ ) located three miles southwest of Mercury, Nevada (Station No. 23). Upper-air observations (radiosondes) are taken twice daily from DRA. DRA has been in operation since June 1978. DRA was built to replace a similar observatory that was located in Yucca Flat (UCC, elevation $3924 \mathrm{ft}$, Station No. 6) from January 1962 through April 1978. Consequently, surface and upper-air observations are also available from UCC for 1962-1978.

A key component of the MIDNET system is the Meteorological Data Acquisition System (MEDA). MEDA consists of an enclosed trailer, a portable 10-m tower, an electric generator (where needed), a microprocessor, and a microwave radio transmitter. Wind speed and direction sensors are located on booms oriented into the prevailing wind direction and at a minimum distance of two tower widths from the tower. Wind sensors are located $10 \mathrm{~m}$ above the ground. 
Wind and temperature data have been collected on the NTS for more than 25 years. These and other meteorological data have been compiled into a comprehensive climatological database for the NTS. The MEDA data are specially useful in assessing boundary layer flow regimes on the NTS. MEDA station distribution and density (see Fig. 1) are sufficient to document individual basin flow regimes and potential interbasin air exchanges.

Ambient temperature and relative humidity sensors are located at the 3-m level. A total of 40-50 MEDA stations are located on or around the NTS (Fig. 1) to ensure that meteorological conditions are thoroughly documented for the complex terrain environment found on the NTS.

Wind direction is measured to two degrees of azimuth and wind speed is accurate to $0.15 \mathrm{mph}$. Wind data are collected as 4-minute averages and are transmitted via microwave to a central processor every 15 minutes. These data are checked operationally by the duty forecaster and quality control is assured by the WSNSO climatologist. Plotted wind products are generated every 15 minutes for operational use. The data are stored and archived for climatological purposes.

MEDA temperature is accurate to 0.035 percent between $0^{\circ} \mathrm{C}$ and $40^{\circ} \mathrm{C}$. Temperature measurements are ins!antaneous and are taken every 15 minutes at all MEDA. stations. These data are also tr ansmitted via microwave to a computer for processing, display, and archiving.

To utilize the most representative meteorological data available for NTS sources, cloud observations from DRA were melded with the concomitant MEDA winds from Mercury and Pahute Mesa. Similarly, the cloud observations from UCC were melded with MEDA wind data from Yucca and Frenchman Flats. The straight-line distance from DRA to Mercury is 3 miles; from UCC to Frenchman Flat, 12 miles; and from DRA to Pahute Mesa, 40 miles.

Cloud cover observations needed as input to the STAR (Stability Array) program are available from DRA (1978-present) and from UCC (1962-1978). Based on the available data, the cloud cover climatology from DRA and UCC are quite compatible. For example, UCC experiences 192 clear days annually while DRA has 191 days. In addition, the average annual sky cover, in tenths, from sunrise to sunset for both stations is 3.9 tenths. The total number of cloudy days for UCC is 81 days and 88 days for DRA, annually. Therefore, the cloud cover observations from DRA and UCC can be considered as representative for most of the NTS.

In a study of precipitation on the NTS, Quiring (1983) found that the northwest part of the NTS, including Pahute Mesa, is clearly an area of diminished precipitation for the given elevation (6500 ft). Furthermore, the total annual precipitation for Pahute Mesa (9.5 inches) is more compatible with that from DRA (7.6 inches) than from UCC (6.9 inches). Consequently, assuming that cloud cover is directly related to precipitation, it logically follows that the cloud cover for Pahute Mesa is better represented climatologically by the cloud observations from DRA.

\section{CONCLUSIONS}

Based on the above considerations and on the limitations of CAP88; the cloud cover data from DRA were considered to be representative of Pahute Mesa. Therefore, atmospheric soundings and cloud-cover observations from DRA will be melded with MEDA surface wind data from Pahute Mesa for input to the STAR program to provide the very best data for calculating transport and dispersion processes. 


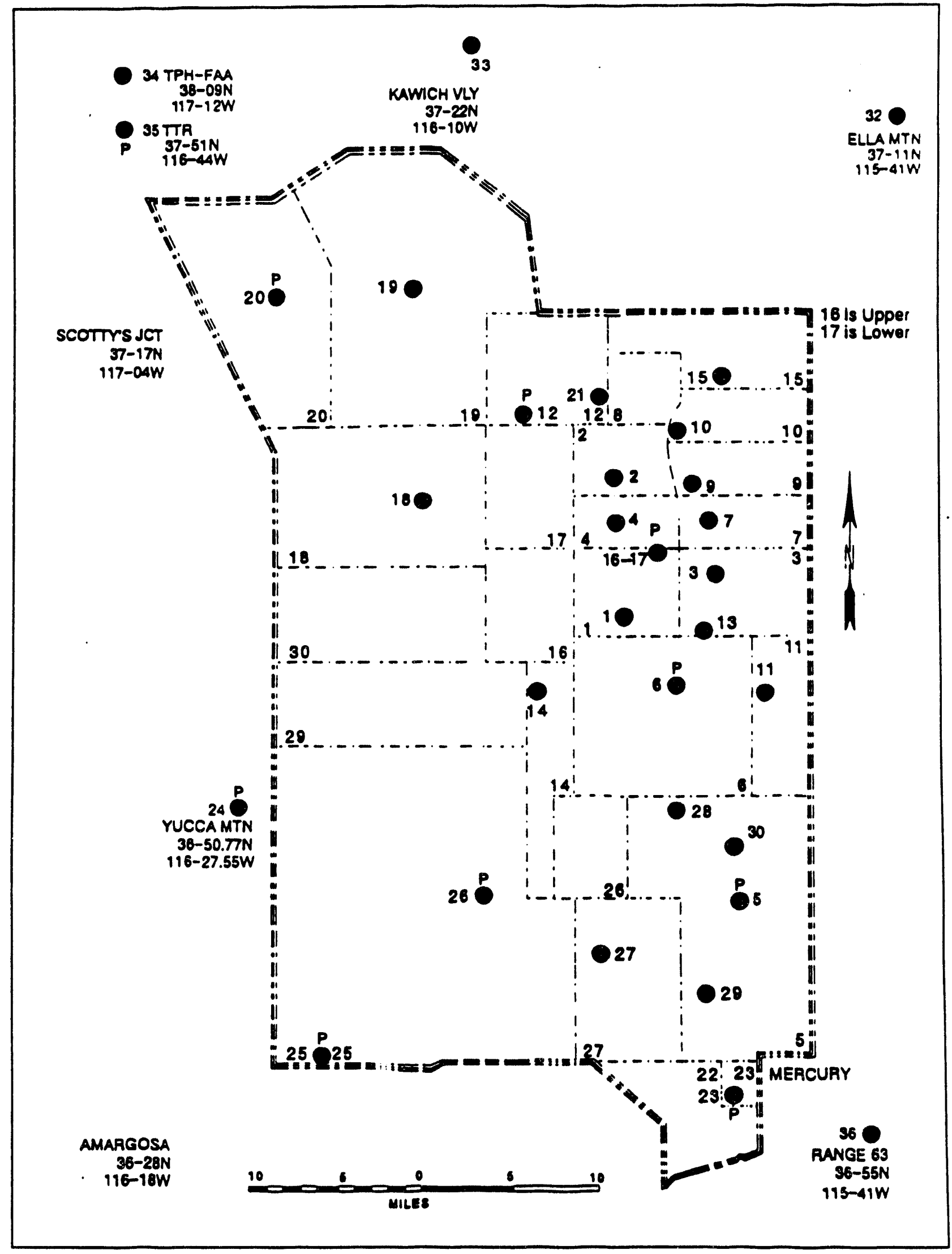

Figure I.1. Location of MEDA Stations on the NTS 
For sources in Yucca Flat and Frenchman Flat, the cloud cover data from UCC were considered to be the most representative. Yucca Flat and Frenchman Flat are adjoining valleys of similar soil and vegetation types and similar meteorological climatological conditions.

For sources at Mercury, the cloud observations from DRA are representative. DRA is only 3 miles from Mercury.

The STAR file is a matrix that includes six Pasquill stability categories (A through $F$ ), six wind speed categories, and 16 wind sectors from wind roses calculated for each specified MEDA station on the NTS.

Reference: Quiring, R.F., "Precipitation Climatology for the Nevada Test Site," NOAAWSNSO, Las Vegas, NV, WSNSO 351-88, 34 pp., 1983. 
APPENDIX J

SUPPLEMENTAL INFORMATION 


\section{COMPARISON WITH PREVIOUS YEAR'S DATA}

Maximum Potential Individual EDE: $1993-3.8 \times 10^{-3} \mathrm{mrem}$ (38 nSV)

$1992-1.2 \times 10^{-2} \mathrm{mrem}(120 \mathrm{nSv})$

$1991-8.6 \times 10^{-3} \mathrm{mrem}(86 \mathrm{nSv})$

$1990-5.8 \times 10^{-3} \mathrm{mrem}(58 \mathrm{nSv})$

In 1990 containment pond evaporation of HTO was added to the NTS source term, the tritiated water effluents from the tunnels were 3 times higher in 1991. In 1992, there was a $15 \%$ increase in HTO effluents and the STAR for the tunnel area was developed that slightly changed the offsite distribution of the effluent. In 1993 tunnel effluent decreased because of sealing the tunnel drainage systems.

\section{COLLECTIVE EFFECTIVE DOSE EQUIVALENT}

The maximum potential collective effective dose equivalent to the 21,750 people who live within $80 \mathrm{~km}$ of the NTS emission sources was 0.012 person-rem in 1993 due principally to tritium exposure. This was less than last year because of the reduced tritium emissions. The collective EDE data are based on distance and direction from each of the sources of emission on the NTS. These data are displayed in the rightmost column of Table 5. The collective EDE is the sum of the EDE to the community from each area multiplied by the population of the community..

Maximum Potential Collective EDE (person-mrem) by NTS Source:

\begin{tabular}{ll} 
Area 3 & 0.0013 \\
Area 5 & 0.00006 \\
Area 9 & 0.0011 \\
Area 12 & 0.0094 \\
Area 19/20 & 0.0000027 \\
Mercury & 0.00000019 \\
\cline { 2 - 2 } & $\begin{array}{l}11.86 \text { person-mrem } \\
\text { (0.012 person-rem) }\end{array}$
\end{tabular}

The higher potential population doses from Area 12 are due to the conservative assumptions about evaporation of tritium from liquid effluents from the Area 12 ponds. The extent of overestimation can be assessed as follows: calculate the concentration of ${ }^{3} \mathrm{H}$ necessary to cause the CAP88-PC estimate of EDE. The CAP88-PC effective dose equivalent was 0.0034 mrem at Indian Springs due to evaporation of HTO effluent from the tunnels. Using a dose conversion factor of $6.3 \times 10^{-5} \mathrm{rem} / \mu \mathrm{Ci}$ (from DOE/EH-0071) and an inhalation intake of 8400 $\mathrm{m}^{3}$ per year, divide the $0.0034 \mathrm{mrem}$ by $0.063 \mathrm{mrem} / \mu \mathrm{Ci}$ to obtain an intake of $0.054 \mu \mathrm{Ci}$. The $0.054 \mu \mathrm{Ci}$ divided by 1.5 for skin absorption and the inhalation rate of $8400 \mathrm{~m}^{3}$ per year gives an annual average concentration of $4.3 \times 10^{-6} \mu \mathrm{CV} / \mathrm{m}^{3}$ or $4.3 \mathrm{pCV} / \mathrm{m}^{3}$. The 1993 annual average concentration measured by EMSL-LV at Indian Springs was $0.54 \mathrm{pCi} / \mathrm{m}^{3}$ or just 12 percent of the concentration required to deliver the EDE calculated by CAP88-PC.

\section{COMPLIANCE WITH NESHAP}

DOENNV was in compliance with 40 CFR 61, Subpart H, during Calendar Year 1993. Periodic confirmatory measurements and analysis of the NTS environs are provided in Appendices A 
through J plue periodic isokinetic confirmatory sampling at the P-tunnel ventilation duct. These measurements and analysis are the methods of determining NTS effluents presented in the April 24, 1991, meeting between Region IX and DOENV and documented in the 1990, 1991, and 1993 DOENV annual reports. However, we have not received any notification from EPA Region 9 stating that we are in compliance with NESHAP.

\section{COMPLIANCE WITH SUBPARTS Q AND T, 40 CFR 61}

The NTS is regulated by Subpart H. Measurements of radon-220 and -222 have not been made. Short-lived radon daughters would be detectable on particulate filters from air samplers deployed around the Radioactive Waste Management Facility.

\section{RADON EMISSIONS FROM U-238 AND TH-232 SOURCES}

Material from Mound Applied Technologies is stored in cargo containers at the waste management site in Area 5. TLDs placed around the containers have not detected an increase in gamma exposure that would occur as radon daughters accumulate in the cargo containers.

\section{NON-DISPOSALNON-STORAGE SOURCES OF RADON EMISSION}

None of these sources exist on the NTS.

\section{NESHAP QA PROGRAM}

Provisions in Method 114 described in Appendix B of 40 CFR 61 are related to continuous monitoring of major sources. The NTS has only minor sources.

\section{STATUS OF TIGER TEAM FINDINGS}

The Status of DOENV's responses to the 1989 Tiger Team Compliance Assessment Findings relevant to radioactive air emissions were provided in the CY 1991 annual NESHAP report. 

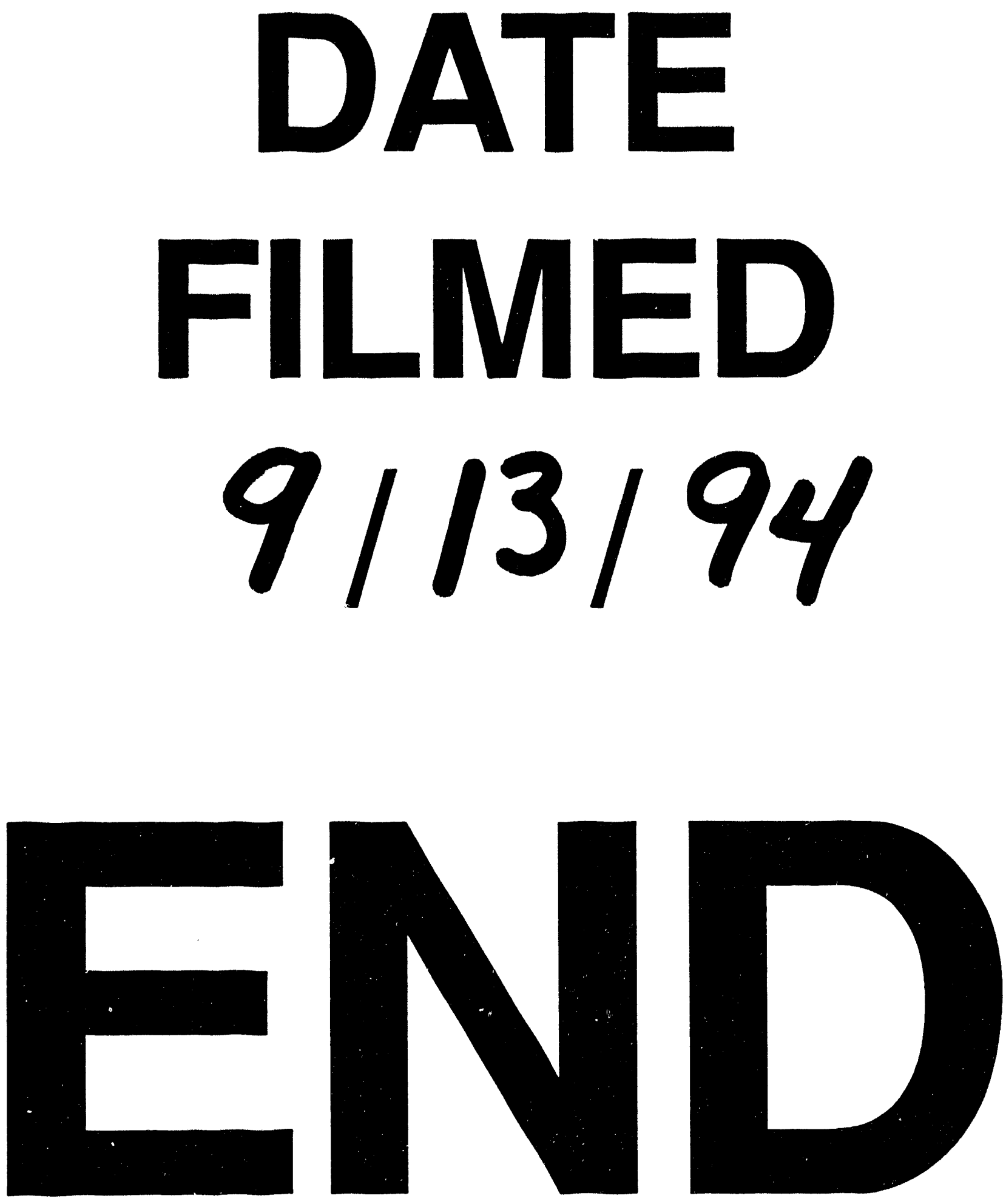


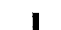

